\title{
Different processes affecting long-term Ravenna coastal drainage basins (Italy): implications for water management
}

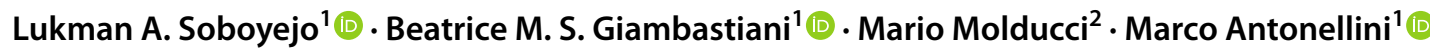

Received: 21 December 2020 / Accepted: 9 July 2021 / Published online: 26 July 2021

(c) The Author(s) 2021

\begin{abstract}
The low-lying coastal basins of Ravenna (Italy) are at or below mean sea level and currently undergoing land subsidence, which exposes the basins to frequent inundation and groundwater and soil salinization. The surface water drainage becomes necessary to lower the water table head and further prevent flooding and waterlogging. The study examines the evolution of drainage apropos to climate change and land subsidence in the three main Ravenna coastal basins. Our findings show that the evolution of drainage is influenced by land subsidence, climate change variability, droughts, vertical seepage, and local water management. Land subsidence causes an increase in upward-directed vertical seepage of saline water through the shallow unconfined aquifer into the drainage channels of the coastal basins, thus leading to an increase in drainage through time. At a seasonal timescale, the rate of pumping depends on antecedent rainfall and soil-water storage. The warming extremes indices, specifically drought indices, show to be more significant than rainfall indices trends to monitor drainage evolution. Drought indices permit easy comparison of dryness or wetness severity with drainage evolution along their time scale. The co-occurring anthropogenic and natural factors involving in the increasing drainage rate will affect decadal and seasonal water management policies in the area. The implications of increasing drainage rates, long periods of drought with limited rainfall, and increasing temperature will further worsen freshwater availability in this coastal area already experiencing soil and water salinization. However, drainage of this low-lying territory has effectively mitigated rising water tables and avoided flooding. Our study has shown that each coastal basin behaves differently in terms of sensitivity to land subsidence and climate extremes. Therefore, when using drainage data time series for water management purposes, one should account for past management practices and for the specific sensitivity of each basin to external factors.
\end{abstract}

Keywords Climate change $\cdot$ Land subsidence $\cdot$ Drainage $\cdot$ Time series analysis $\cdot$ Coastal basin $\cdot$ Seepage

\section{Introduction}

Lukman A. Soboyejo

lukman.soboyejo@studio.unibo.it

Beatrice M. S. Giambastiani

beatrice.giambastiani@unibo.it

Mario Molducci

m.molducci@bonificaromagna.it

Marco Antonellini

m.antonellini@unibo.it

1 Department of Biological, Geological, and Environmental Science, University of Bologna, Ravenna Campus, Via S. Alberto 163, 48123 Ravenna, Italy

2 Consorzio di Bonifica della Romagna, Via A. Mariani 26, 48121 Ravenna, Italy
The coastal cities worldwide, and more so in the Mediterranean, are threatened by sea-level rise (SLR), inundation, storm surges, and precipitation variability (Essink et al. 2010; Nicholls et al. 2007). On top of that, land subsidence poses a severe threat to coastal areas by intensifying the level of exposure to inundation or flood hazards (Galloway et al. 1999; Mimura 2021; Ogie et al. 2018). Climate change and land subsidence co-occurring cause instability of low-lying areas, coastal inundation and erosion, and saltwater seepage from the deepest portion of the aquifer with consequent contamination of freshwater resources (Abdoulhalik and Ahmed 2018; Nicholls et al. 2021; Sestini 1996). On this note, coastal cities and the adjacent rural areas often rely on either non-structural or structural measures (engineering structures) or both to mitigate inundation and protect a 
fragile water infrastructure consisting of drainage channels, dams, levees, dikes, detention reservoirs, seawalls, polders, pumping stations, floodgates, and more (Nazarnia et al. 2020; Ogie et al. 2018).

Climate change and land subsidence have a profound role in the severity of coastal flooding, with far-reaching water management, flooding infrastructure, ecological and socio-economic implications for low-lying coastal cities and polder systems. These two main drivers of coastal flooding have attracted the interest of many scientists and researchers in recent years (Essink et al. 2010; Mimura 2021). Recognizing the role these two drivers have on coastal surface water drainage through time is imperative to strategic water planning and development of coastal urban areas and their drainage waterways. Past and recent studies have greatly improved our understanding of these drivers, but correlation with seawater seepage and drainage is widely unrecognized in many coastal studies.

Coastal regions with low elevations and high populations are at the highest risk of inundation (Mimura 2021; Syvitski et al. 2009). The appealing nature of the coastal areas has accelerated human migration to the area, thus promoting rapid urbanization, tourist resort growth, and intensive farming. In the process, the natural environment and hydrological cycle are modified in many ways, viz drainage, land reclamation, discharge of sewage contaminants into coastal waters, river modification, sand mining, hydrocarbon production, and more. These kinds of human interventions promote saline intrusion of the shallow coastal aquifer and have a long-term impact on freshwater management and water infrastructure (flooding), which could be costly to mitigate in the future (Nicholls et al. 2007, 2021 ).

In the Ravenna coastal basins (Northern Italy), a surface water drainage system and pumping stations are necessary to manage floodwater and lower water table heads (Giambastiani et al. 2007). The initial objective of pumping was land reclamation for allowing agricultural activities, protect infrastructure, accommodate human settlement (Antonellini et al. 2015; Giambastiani et al. 2020; Teatini et al. 2005, 2006). Subsequently, land drainage and pumping, managed by the Land Reclamation Consortium (LRC), allows farmland activities by controlling vadose zone depth and maintaining constant water table depth in the range of 1.5-2.0 m below the ground during the year (Antonellini et al. 2015, 2019).

Relative Sea Level Rise (RSLR), which includes land subsidence, both natural and anthropogenic, and eustacy, has occurred across the entire coastal areas of the Northern Adriatic Sea and has produced relative ground settlements of meters in Ravenna (Carbognin et al. 2011). The area has suffered from an intensive subsidence rate, up to a maximum value of $110 \mathrm{~mm} / \mathrm{year}$ in the 1970s, during the high economic boom due to deep groundwater natural gas withdrawals (Teatini et al. 2005). More recently, the rates of subsidence have significantly decreased in many areas due to strong mitigation law imposed on groundwater exploitation (Carminati and Martinelli 2002), but they still remain important in some places like the coastal area (Artese et al. 2016; Bitelli et al. 2015; Cerenzia et al. 2016; Teatini et al. 2005). The subsiding land raised the need to pump more water out of the coastal basins to keep pace with the rising groundwater level (Antonellini et al. 2019). At the same time, freshwater availability in the area is becoming scarce due to limited rainfall, severe drainage, saline intrusion, and long periods of drought (Antonellini et al. 2008). The climate and weather variability in the area has intensified seasonal imbalance in groundwater budget, characterized by water deficit in the summer and surplus in winter when drainage is at its maximum peak (Benini et al. 2016; Greggio et al. 2018).

The general aim of our paper is to explore correlations between these aspects and to show how drainage in different coastal basins may be more or less sensitive to land subsidence, water management practices, and climate variability (i.e., droughts, climate extremes, etc.). In this context, our work adds novelty and is important for coastal water management. In order to achieve our objective, we compute local climate extreme indices as part of the necessary analysis required to understand drainage evolution. The study prioritizes the need to better understand drainage evolution in coastal basins under long-term and seasonal conditions. A previous study (Giambastiani et al. 2020) on factors affecting water drainage long-time series in the Quinto coastal basin of Ravenna (Fig. 1) proves that the amount of extra water entering the aquifer is due to vertical seepage from the bottom of the upper sandy portion of the surface aquifer. This extra amount of water is caused by an increase in hydraulic head difference driven by land subsidence rate, while rainfall time series analysis (1971-2017) and land-use change do not show a well-defined trend and play no important role in justifying the increasing drainage trend. More study is required to understand these above-mentioned relationships and the need to understand different coastal basins behavior to drought indices and other important extremes in a similar timeframe prompted the current research work.

The novelty of our study, however, is showing that there is no single process controlling a change in drainage but there are many and complexly interrelated. Land subsidence, climate variability and extremes (droughts) as well as past management practices all play an essential role. We show that there is a wide range of factors that affect drainage time series and knowledge gained from a single basin cannot be extrapolated to the whole coastal area.

The study-specific objectives are: (1) to examine the behavior of long-term drainage data in the lowest 3 coastal basins of Ravenna and further compare it with the hydroclimatic component, and (2) to identify the main factors contributing to surface water drainage through time in the 

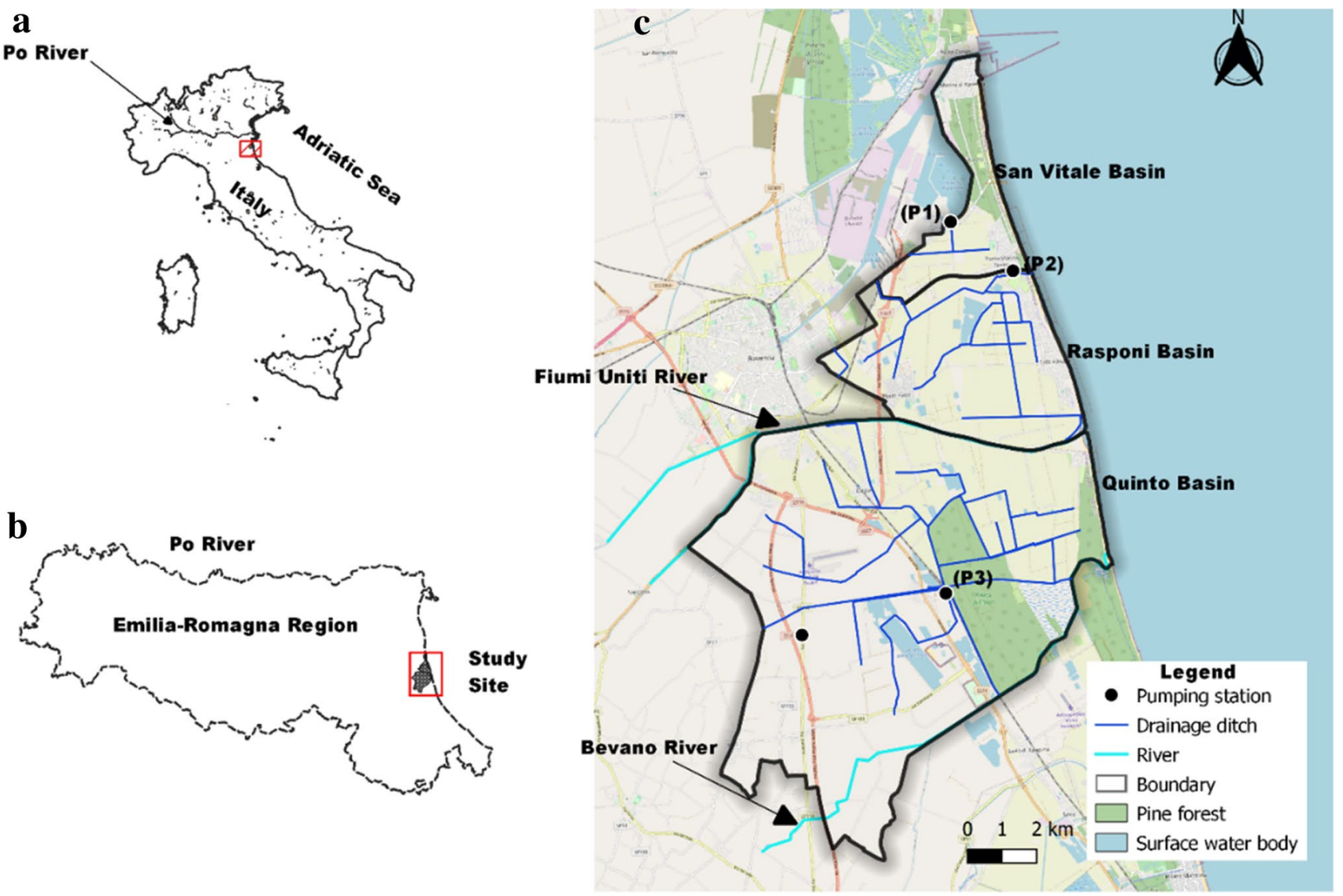

Fig. 1 Location maps of the study area (a) and the Emilia-Romagna Region (b) the three low-lying coastal basins, along with the main hydrology, pumping stations and surface drainage network are shown in (c)

area by considering a wide range of climate extremes, which include both precipitation and temperature indices. The connection highlighted in our study area provides a clear and complete description of the processes occurring in low-lying coastal areas subjected to drainage, subsidence, and salinization and could serve as a motivation and reference for other similar coastal basins worldwide. Moreover, the findings can help to take management actions for the sustainable use of water resources in coastal areas facing similar problems.

The paper is structured in a first general description of the study area, including the water management and drainage system, hydrogeological, and climate setting (Sect. "General description of the area"). Following, Sect. "Data acquisitions and elaboration" describes the methodology applied for drainage, climate and subsidence time series analysis and modelling, as well as water budget calculation to examine the effect of change in hydrologic cycle component on the water resources of the studied basins. In Sect. "Results and discussion", the drainage trends are compared and discussed with regards to climate extremes and subsidence trends; finally, the main findings are reported in the conclusions (Sect. "Summary and Conclusions").

\section{Materials and methods}

\section{General description of the area}

The city of Ravenna is in a low-lying coastal plain situated at the eastern end of the Emilia-Romagna region (North-Eastern Italy), about $60 \mathrm{~km}$ south of the Po River delta (Fig. 1). Ravenna is one of the oldest Italian towns founded in the VII century BC; it harbors great historical monuments that attract the interest of tourists all around the world (Teatini et al. 2005). The presence of artistic monuments and proximity to the sea has promoted a wide range of socio-economic and land-use activities in the area. The city land elevation has a range of 0.5 to $-0.5 \mathrm{~m}$ a.s.l. (Greggio et al. 2018). Currently, the Ravenna coastal area is composed of wetlands, lagoons, urbanized areas with industrial facilities, reclaimed agricultural land, rivers, canals, and complex drainage network systems (Giambastiani et al. 2008; Greggio et al. 2012).

The studied coastal area includes three mechanically drained coastal basins: San Vitale Basin (1,080 ha), Rasponi Basin (2,639 ha), and Quinto Basin (9,200 ha). The Quinto 
basin is the largest low-lying basins in the area, with a surface covering $10 \%$ of the Ravenna province, whereas the San Vitale and the Rasponi basins cover approximately 3\% and $1 \%$, respectively. The Quinto basin land use includes farmland, pine forests, beaches, and gravel quarries (Giambastiani et al. 2020; Mollema et al. 2012). The Rasponi basin is mostly supporting agricultural activities, while the San Vitale basin is a small-reclaimed area with natural and human-made features such as the pine forests, recreational areas, coastal lagoons, and farmlands (Giambastiani et al. 2007). Together, they cover the entire southern coastal zone of Ravenna.

\section{Water management and drainage system}

Water management along the Po river plain has always been a necessity for effective and sustainable farming since 2000 years ago (Antonellini et al. 2015; Greggio et al. 2018). The Romans used hydraulic techniques to distribute water from the Apennines down to the Adriatic Sea (Port of Ravenna) through mountainous, hilly, and lowland territories characterized by different problems and characteristics. The hydraulic interventions on the natural river networks, such as the digging of canals and river dikes construction, had the objective to ensure efficient use of land for farming (Stefani and Zuppiroli 2010). Nowadays, the entire stretch of the Emilia-Romagna plain has more than 30 pumping stations with a network of ditches, canals, and rivers interconnected to one another (Antonellini et al. 2019).

The Ravenna municipality accommodates nine active and three emergency pumping stations. The study area includes three mechanical pumping stations (called $P 1, P 2$, and $P 3$ in Fig. 1). The extensive land reclamation and impoldering system in the area emerged in the twentieth century when the existing hydraulic infrastructure was designed and constructed (1920 and 1960) (Vandenbohede et al. 2014). Due to the low topography, the water lifted from the basins is discharged directly into the Adriatic sea by the connected pumps and drainage channels (Giambastiani et al. 2020; Greggio et al. 2018; Stefani and Vincenzi 2005). During the summer period (Jun-Sept), the drainage canals receive surface water from adjoining rivers through a system of connected pipes and sluice gates. This method of water distribution system promotes efficient water management for drainage and irrigation distribution to support rural, industrial, recreational, and urban activities. At the same time, the Land Reclamation Authority manages water scarcity emergencies in summer and drought periods through several water-saving techniques such as the reduction in the withdrawal of surface water, rationalization of water distribution (Greggio et al. 2018), and inter-basin water transfers (IBWT) when and where necessary.

\section{Hydrogeological settings}

The geological setting of the studied area is composed of a sequence of layered sediments deposited during the Quaternary and Upper Pliocene, which represent different sedimentary environments (Gambolati et al. 1991; Teatini et al. 2005). The shallow coastal aquifer is composed of Holocene sediments, and the Pleistocene continental clay below forms the impermeable bottom confining layer. The coastal sediment of the upper shallow aquifer was transported and deposited by sea-level fluctuations (Amorosi et al. 1999; van Straaten 1970) due to the barrier-lagoonestuary natural dynamic behavior (Fig. 2). The shallow coastal aquifer sedimentology includes wedge-shaped dunes and beach deposits intercalated with fine sediment and frequent thin (centimeters) peat layers formed in lagoons, marshes, and alluvial plains. This dynamic nature of the coastline resulted in alternating layers of sediments that correspond to multiple parallel dune belts formation (Giambastiani et al. 2007).

In particular, the shallow coastal aquifer is composed of two sandy units separated by alternating clayey and sandy loam layers (prodelta deposits). The sandy units have relatively thick medium-grain sand in the upper part of the aquifer (0-10 $\mathrm{m}$ thickness) and fine-grained sand ( -21 to $-26 \mathrm{~m}$ thickness) in the lower part (Giambastiani et al. 2020; Mollema et al. 2012). Further inland, the two central sand units are laterally connected to gravel deposits, which separate them from the lagoon deposits. The siltyclay basement is at a depth varying from -15 to $-20 \mathrm{~m}$ in the west and from -25 to $-30 \mathrm{~m}$ in the east (present shoreline) (Amorosi et al. 2008; Campo et al. 2017).

\section{Climate of the area}

The climate of the Emilia-Romagna plain is peculiar because of the bordering mountains and the sea-the Apennines to the south, the Alps to the north, and the Adriatic Sea to the east. The orography and marine area are significant drivers influencing the spatial distribution of temperature and precipitation in the region (Tomozeiu et al. 2006), particularly for the coastal cities (ISPRA 2013; Tomozeiu et al. 2006).

During the past 48 years, the annual precipitation of the area varies between 300.2 and $1063.3 \mathrm{~mm}$, with an average yearly value of $639 \mathrm{~mm} /$ year and the mean annual temperature varies from $10.8{ }^{\circ} \mathrm{C}$ to $15.5^{\circ} \mathrm{C}$ with an average value of $13.5^{\circ} \mathrm{C}$ /year. The annual rainfall was the lowest in 1987 $(\sim 489 \mathrm{~mm})$ and the highest in $1997(\sim 774 \mathrm{~mm})$. In the past decade, the rainfall over the area reaches its maximum during the autumn. 


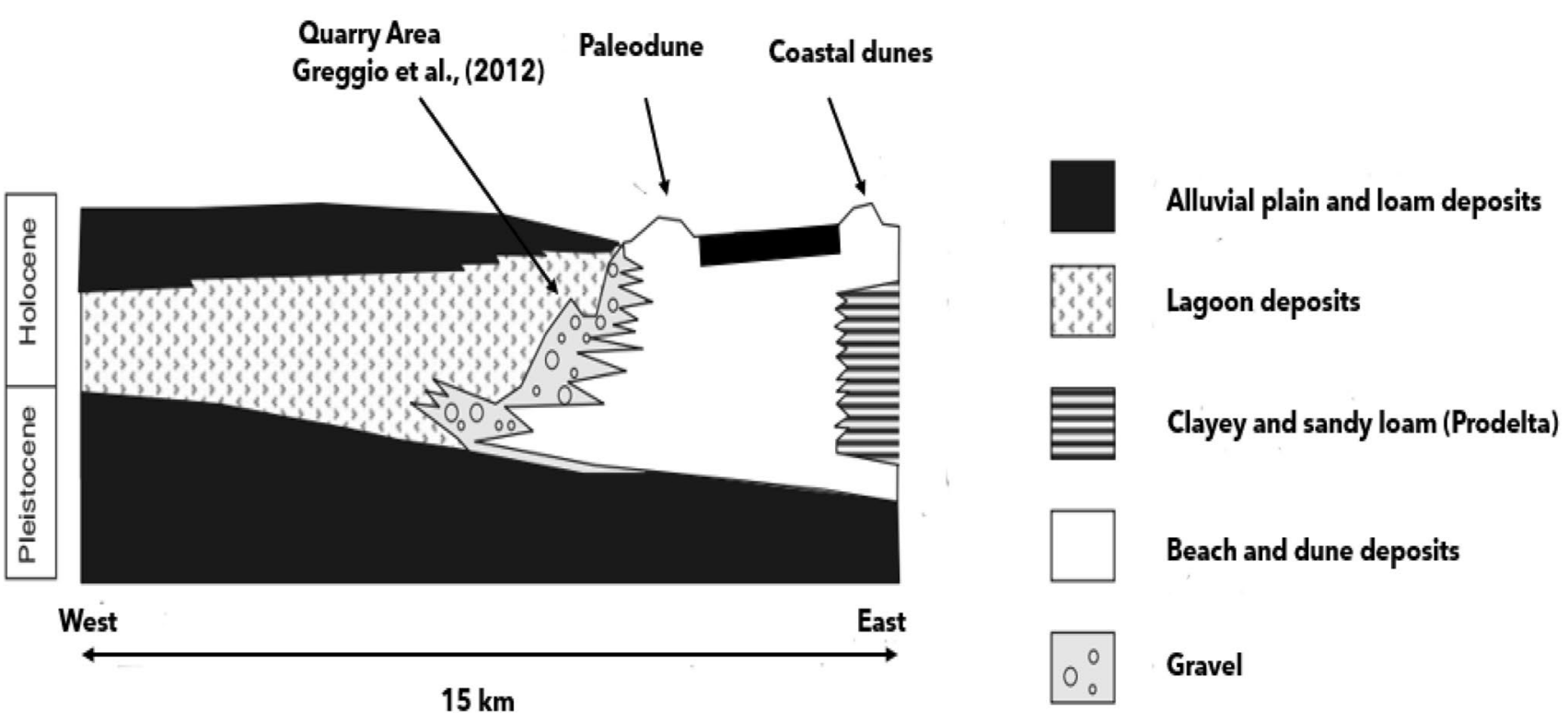

Fig. 2 Geological cross-section showing the stratigraphy and lithology of the Ravenna shallow coastal aquifer. Image modified from Mollema et al. (2012)

\section{Data acquisitions and elaboration}

This study focuses on the use of different statistical methods to analyse the coastal drainage data (Time Series Analysis, Local Regression Model), DEM elaborations for land subsidence mapping, and indexes computed from daily meteorological data from 1971 to 2018. We also elaborate sub-periods water budgets of the coastal basins. A flowchart diagram of the methodologies is in Fig. 3.

\section{Drainage data}

The pumping data of coastal watersheds (San Vitale, Rasponi, and Quinto basins) were obtained from the original bookkeeping records of LRC from 1971 to 2018. It is worth mentioning that data are not available between 1988 and 1991 for both Rasponi and San Vitale basins. The daily hours of operation were recorded in a logbook sheet of each basin and digitized for future elaboration. Computationally, the daily drained water $\left(\mathrm{m}^{3} /\right.$ day $)$ of each station was estimated by multiplying the flow rate of each pump $\left(\mathrm{m}^{3} / \mathrm{h}\right)$ by the duration of its operation (h). Afterward, the equivalent depth of the water columns (m/day) in each of the basins was obtained by dividing the total volume of water drained per day by the drained area of the individual basin $\left(\mathrm{m}^{2}\right)$.

\section{Subsidence data}

The subsidence surveys of each coastal basins were obtained from literature data published by Teatini et al. (2005) from 1972 to 1992 in the following sub-periods: 1972-1977,
1977-1982, 1982-1986, 1986-1992; and from the Regional Agency for Prevention, Environment, and Energy of EmiliaRomagna (Arpae website; www.arpae.it/index.asp?idliv ello=1414) from 1992 to 2016 for sub-periods: 1992-2000, 2002-2006, 2006-2011, and 2011-2016. The subsidence data were acquired with topographic and Interferometric Synthetic Aperture Radar (InSAR) techniques calibrated on a 2005 topographic survey and a GPS permanent network (Cerenzia et al. 2016; Teatini et al. 2005). The data were elaborated with the QGIS software to obtain subsidence maps and isokinetics (mm/year) for the different sub-periods.

\section{Climate data and climate extremes}

The daily meteorological data-minimum, maximum, and mean of precipitation $(P)$ and temperature $(T)$-were taken from different meteorological stations within the Ravenna area to get the longest time dataset possible. The assumption is that the dataset obtained from each weather station has insignificant differences among individual stations, because the stations are a few $\mathrm{km}$ apart. The dataset covers a period from 1971 to 2018 and it is relevant for the three coastal basins studied. The daily dataset for the periods 1971-1975 and 1976-2018 was retrieved from the Arpae periodical Annals (https://www.arpae.it/) and the Arpae DEXT3R website (https://simc.arpae.it/dext3r/), respectively.

The core set of descriptive climate extreme indices used in our study was developed by the joint CCl/CLIVAR/JCOMM Expert Team on Climate Change Detection and Indices (ETCCDI) in 1999. The ETTCDI indices include temperature and precipitation indices. 


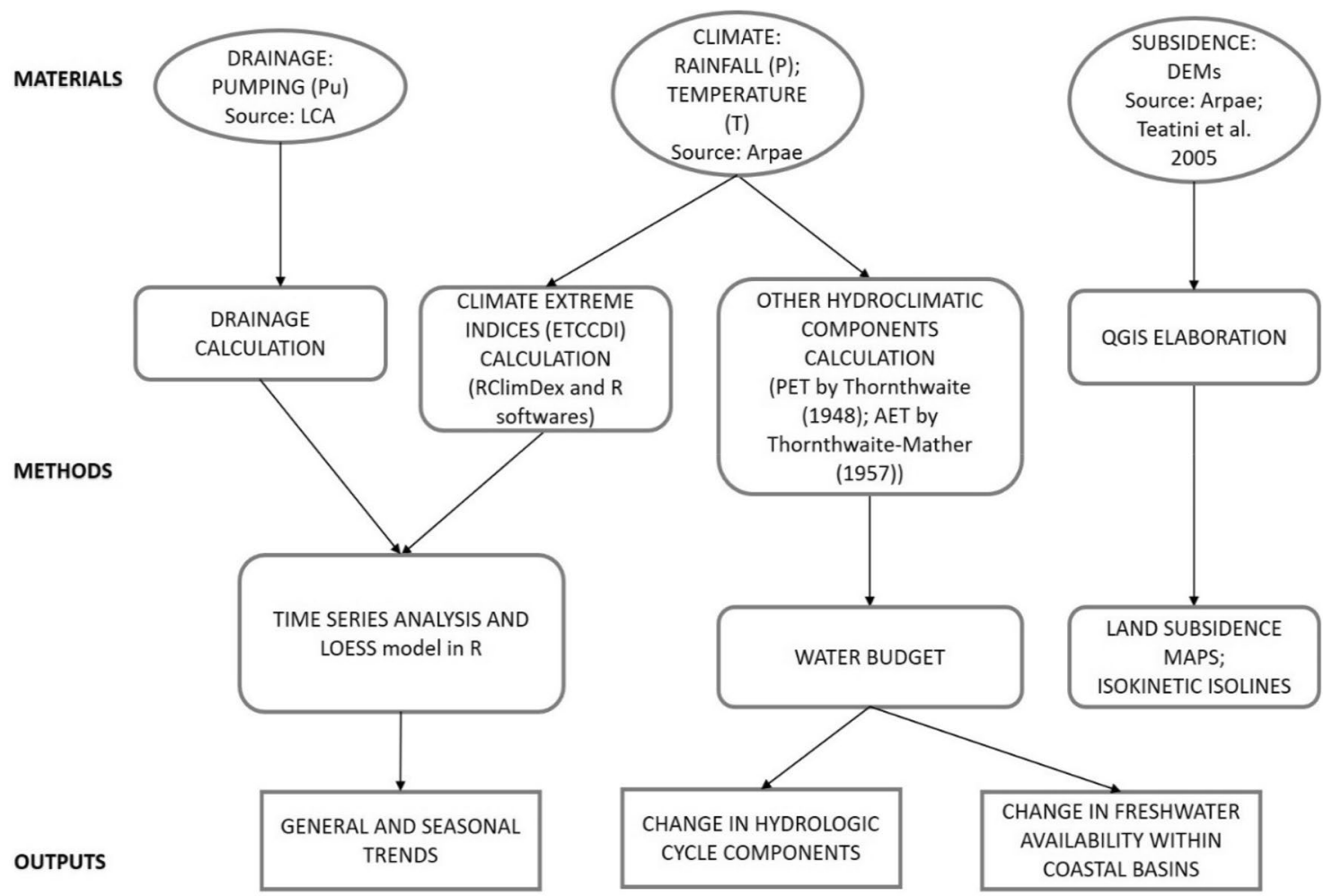

Fig. 3 Flowchart of the methodology used to assess the potential threats caused by land subdidence, and climate variability and change in the study area

Indices calculation allows straightforward monitoring of trends that can potentially cause stress to coastal structures, humans, and the natural environment in a short timeframe (ISPRA 2013; Zhang et al. 2011). In achieving this, we used 13 temperature and 10 precipitation indices from the list of ETCCDI indices and two additional drought indices (Table 1).

The climate extremes indices were calculated using the RClimDex software developed by ETCCDI. The RClimDex is a $R$-based software (Zhang et al. 2018) that provides a user-friendly interface to compute indices of climate extremes and allows for user-defined input when calculating the indices. The drought indices were calculated using the SPEI and SPI package present in R (https://www.r-project.org/). The SPI and SPEI calculation depends on the probability of events (such as $P$ and $T$ ) transformed into a standardized series for the desired timescales ranging from 3 to 48 months (Hayes et al. 1999; McKee et al. 1993; WMO 2012). However, the most suitable timescale to monitor long-term hydrological changes is at least 24 months (such as reservoir level, groundwater, streamflow) (Hayes et al. 1999; WMO 2012).

\section{Water budget calculation}

Water budget evolution through time in the different coastal basins needs to be quantified to examine the effects of change in hydrologic cycle components on freshwater resources. The water budget analysis, in fact, is vital for assessing changes in freshwater availability within coastal basins. The irrigation and drainage activities in the coastal basins make water budget analysis complex to compute. The topography of the coastal basins is flat and the drainage system mainly collects the runoff water (Mollema et al. 2012). The general formulation of water budget is as follows:

Input $=$ Output $\pm \Delta S$

Potential evapotranspiration (PET) and actual evapotranspiration (AET) were obtained using the Thornthwaite equation (1948) and the Thornthwaite and Mather Procedure $(1955,1957)$, respectively. The change in soil water storage $(\Delta S)$ and infiltration (Infl) were also included in the calculation. The Thornthwaite-Maher procedure estimates for different parameters such as the soil moisture balance, recharge, water deficit (Steenhuis and Van Der Molen 1986). 
Table 1 Descriptive table of the climate extreme indices selected

\begin{tabular}{|c|c|c|c|}
\hline ID name & Index name & Definitions & Units \\
\hline \multicolumn{4}{|c|}{ Temperature-based Indices } \\
\hline \multicolumn{4}{|l|}{ Absolute } \\
\hline TXx & Max Tmax & Maximum monthly value of daily maximum temperature & ${ }^{\circ} \mathrm{C}$ \\
\hline TXn & Min Tmax & Monthly minimum value of daily maximum temperature & ${ }^{\circ} \mathrm{C}$ \\
\hline $\mathrm{TNx}$ & Max Tmin & Maximum monthly value of daily minimum temperature & ${ }^{\circ} \mathrm{C}$ \\
\hline $\mathrm{TNn}$ & Min Tmin & Monthly minimum value of daily minimum temperature & ${ }^{\circ} \mathrm{C}$ \\
\hline \multicolumn{4}{|l|}{ Percentile } \\
\hline TX10p & Cool days & Percentage of days when $\mathrm{TX}<10$ th percentile & $\%$ \\
\hline TX90p & Warm days & Percentage of days when TX $>$ 90th percentile & $\%$ \\
\hline TN10p & Cool nights & Percentage of days when $\mathrm{TN}<10$ th percentile & $\%$ \\
\hline TN90p & Warm nights & Percentage of days when $\mathrm{TN}>$ 90th percentile & $\%$ \\
\hline \multicolumn{4}{|l|}{ Duration } \\
\hline GSL & Growing season length & $\begin{array}{l}\text { Annual (1st Jan-31st Dec in NH, 1st July-30th June in SH) } \\
\text { count between the first span of at least } 6 \text { days with TG }>5{ }^{\circ} \mathrm{C} \\
\text { and first span after 1st July (1st January in SH) of } 6 \text { days with } \\
\text { TG }<5^{\circ} \mathrm{C}\end{array}$ & days \\
\hline WSDI & Warm spell duration indicators & $\begin{array}{l}\text { Annual count of days with at least } 6 \text { consecutive days when } \\
\text { TX }>90 \text { th percentile }\end{array}$ & days \\
\hline CSDI & Dry spell duration indicators & $\begin{array}{l}\text { Annual count of days with at least } 6 \text { consecutive days when } \\
\text { TX }>10 \text { th percentile }\end{array}$ & days \\
\hline \multicolumn{4}{|l|}{ Threshold } \\
\hline SU - 25 & Summer days & Annual count when $\mathrm{TX}($ daily maximum $)>25^{\circ} \mathrm{C}$ & days \\
\hline FD - 5 & Frost days & Annual count when $\mathrm{TN}$ (daily minimum $)<5^{\circ} \mathrm{C}$ & days \\
\hline \multicolumn{4}{|c|}{ Precipitation-based indices } \\
\hline \multicolumn{4}{|l|}{ Absolute } \\
\hline RX1day & Max 1-day precipitation & Monthly maximum 1-day precipitation & $\mathrm{mm}$ \\
\hline RX5day & Max 5-day Precipitation & Monthly maximum of consecutive 5-day precipitation & $\mathrm{mm}$ \\
\hline \multicolumn{4}{|l|}{ Percentile } \\
\hline R95p & Very wet days & Annual total PRCP when RR > 95th percentile & $\mathrm{mm}$ \\
\hline R99p & Extremely wet days & Annual total PRCP when RR > 99th percentile & $\mathrm{mm}$ \\
\hline \multicolumn{4}{|l|}{ Duration } \\
\hline CDD & Consecutive dry days & Maximum number of consecutive days with $\mathrm{RR}<1 \mathrm{~mm}$ & days \\
\hline CWD & Consecutive wet days & Maximum number of consecutive days with $\mathrm{RR} \geq 1 \mathrm{~mm}$ & days \\
\hline \multicolumn{4}{|l|}{ Threshold } \\
\hline$R 10 \mathrm{~mm}$ & Number of heavy precipitation days & An annual count of days when PRCP $\geq 10 \mathrm{~mm}$ & days \\
\hline$R 20 \mathrm{~mm}$ & Number of very heavy precipitation days & An annual count of days when PRCP $\geq 20 \mathrm{~mm}$ & days \\
\hline \multicolumn{4}{|l|}{ Others } \\
\hline SDII & Simple daily intensity index & $\begin{array}{l}\text { Annual total precipitation divided by the number of wet days } \\
\text { (defined as PRCP } \geq 1.0 \mathrm{~mm} \text { ) in the year }\end{array}$ & $\mathrm{mm} /$ day \\
\hline PRCPTOT & Annual total wet day precipitation & Annual total PRCP in wet days (RR $\geq 1 \mathrm{~mm})$ & $\mathrm{mm}$ \\
\hline \multicolumn{4}{|c|}{ Drought indices } \\
\hline SPEI & Standardized precipitation index & $\begin{array}{l}\text { Measure of drought using the SPI on time scales of } 24 \text { months; } \\
\text { developed by McKee et al. (1993) }\end{array}$ & No unit \\
\hline SPI & Standardized precipitation Evapotranspiration index & $\begin{array}{l}\text { Measure of drought using the SPEI on time scales of } 24 \text { months; } \\
\text { developed by Vicente-Serrano et al. (2012) }\end{array}$ & No unit \\
\hline
\end{tabular}

While solving this equation, also vertical water seepage in the calculation must be considered. The vertical seepage in a polder is the movement of water under the pressure gradient existing between the aquifer bottom and the water table (which is below sea level in our case). For simplicity, here, we assume an upward seepage $(Q s)$, although a small lateral flow component may be possible in certain conditions (Fig. 4). In general, the change in the amount of water leaving the system $(\Delta \mathrm{Pu}$ and $\Delta \mathrm{AET})$ is equal to the change in the amount of water entering the system $(\Delta P$ and $\Delta \mathrm{Qs})$. In 
Fig. 4 Conceptual diagram showing the cross-section of the shallow coastal aquifer and the anthropogenic and natural processes at work in the Ravenna coastal basins

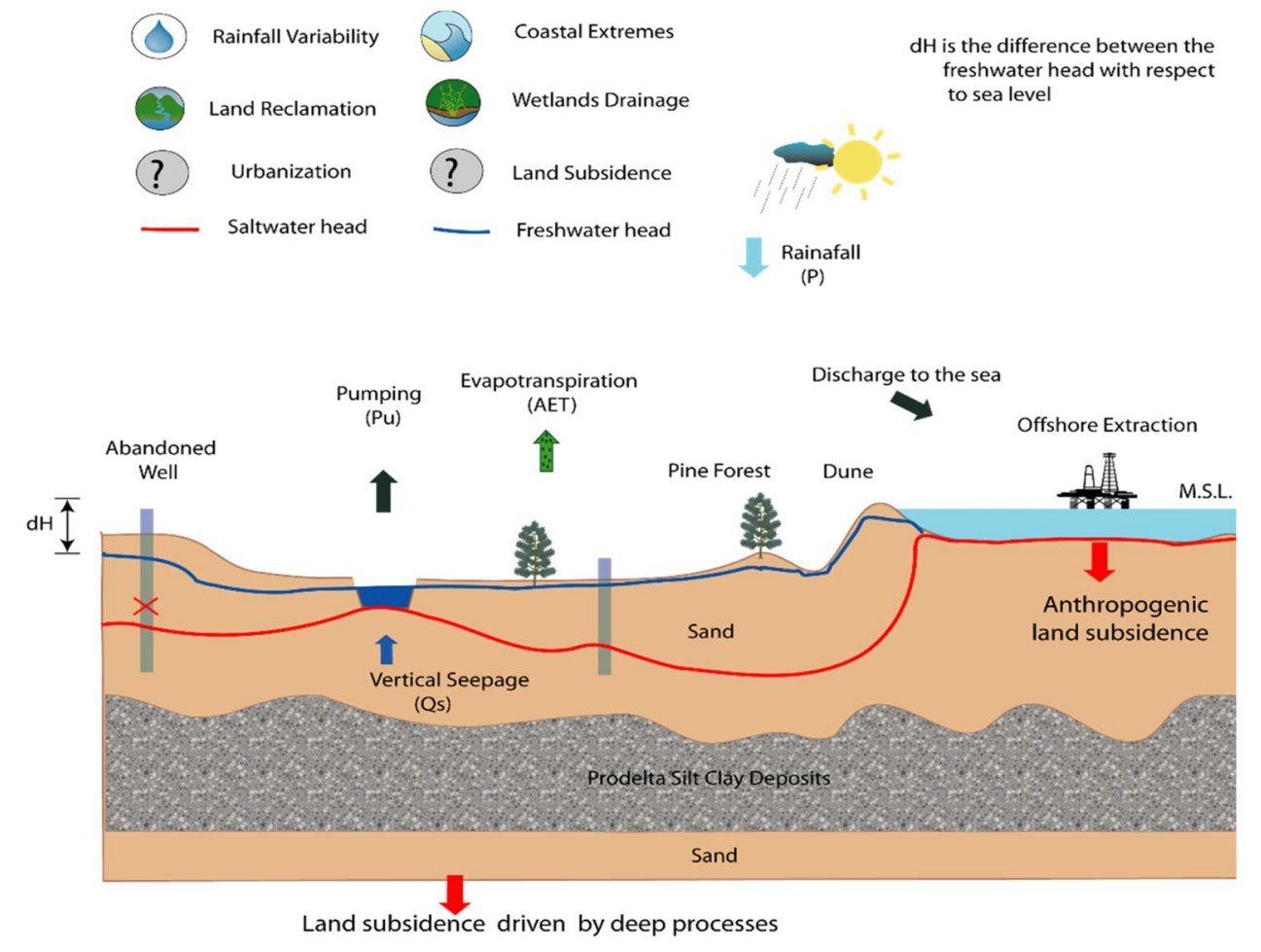

our case, the coastal aquifer is considered a closed system. The $\Delta P$ and $\Delta$ AET are assumed homogeneous throughout the coastal basins. Therefore, the change $(\Delta)$ in the basins groundwater budget variations for different sub-periods (1971-1986, 1987-1996, 1997-2006, and 2007-2018) through time follows Eq. (3) below:

$P+\mathrm{Qs}=\mathrm{ETR}+\mathrm{Pu}$,

$\Delta \mathrm{Qs}=(\Delta \mathrm{ETR}+\Delta \mathrm{Pu})-\Delta P$,

where, $\Delta P$ is the change in precipitation ( $\mathrm{mm} /$ year), $\Delta Q \mathrm{~s}$ is the change in water seepage ( $\mathrm{mm} /$ year), $\Delta \mathrm{ETR}$ is the change in actual evapotranspiration ( $\mathrm{mm} / \mathrm{year}), \Delta \mathrm{Pu}$ is the change in pumping (mm/year).

The annual water budget components are random variables through time.

\section{Timeseries analysis and modelling in $\mathbf{R}$}

We performed a time-series analysis of the $P$, PET, Infl, and $\Delta S$ by applying the locally weighted scatterplot smoothing (LOESS) regression algorithm implemented in $\mathrm{R}$ (https:// www.r-project.org/). The fitting procedure uses a numerical algorithm that prescribes how the value of the regression surface $g\left(x_{i}\right)$ is computed, which is the estimate of the regression surface $g$ at a specific value of any point in the space of the predictors $x$. In the fitting of local regression models, the regression surface properties and the errors require making choices on the specification of properties of the errors and the regression surface. The choices include gaussian or symmetric distribution, constant variance (a priori weights), locally linear or locally quadratic in numeric predictors, neighborhood size, normalization of the scales, dropping squares, and a conditionally parametric subset (Cleveland et al. 2007). However, this study uses identically distributed, Gaussian errors: one numeric predictor $\left(x_{i}\right)$ local regression model. The Gaussian errors have a constant variance $\sigma^{2}$, and working with one numeric predictor assumes $x$ is any value along the scale of measurement of the variable. By definition, the local regression model relates both the response and predictors as follows:

$y_{i}=g\left(x_{i}\right)+\varepsilon_{i}$,

where $\varepsilon_{i}$ is a random error, and $g\left(x_{i}\right)$ is the expected value of $y_{i}(\mathrm{~mm})$.

By letting $\Delta_{i}(x)=\left|x-x_{i}\right|$, let $\Delta_{i}(x)$ be the values of these distances ordered from the smallest to the largest, and using the tricube weight function.

$T(u ; t)=f(x)= \begin{cases}1-\left((u / t)^{3}\right)^{3} & \text { for } 0 \leq u<t \\ 0 & \text { for } 0 \geq t\end{cases}$

The smoothness of the LOESS fitting depends on the specification of the neighborhood parameter $(\alpha>0 ; \alpha$ is the angle of inclination). As $\alpha$ increases, $g$ becomes smoother. Supposedly, $\alpha<0$, and the assumption is that $g$ will be equal 
to the number of points in each smoothing neighborhood $(\alpha n)$ truncated to an integer. Therefore, the defined weight for the $\left(x_{i}, y_{i}\right)$ is given as follows:

$W_{i}(x)=T\left(\Delta_{i}(x) ; \Delta_{(q)}(x)\right)$

When $\alpha \leq 1$, we let $q$ be equal to $\alpha n$ truncated to an integer. For $\alpha>1$, the $W_{i}(x)$ are defined in the same way, but $\Delta_{(q)}(x)$ component is replaced with $\Delta_{(n)}(x) \alpha$. The neighborhood weights called $W_{i}(x)$ either decrease or remain constant as $x_{i}$ increases in distance from $x$. Another parameter is $\lambda$; a parametric function used to describe the regression surface in either linear or quadratic polynomial forms. For $\lambda=1$, the specification is linear, and if $\lambda=2$, the specification is quadratic (see Cleveland 1979; Cleveland et al. 2007; Cleveland and Devlin 1988; Loader 2012, for detailed explanation).

\section{Results and discussion}

\section{Time-series analysis}

The hydroclimatic parameters time-series represent the climate of the coastal basins (San Vitale, Quinto, and Rasponi basins). The LOESS model (Eq. 4) was used to produce average smooth polynomial lines on the annual time series. The changes in the modelled trends (Fig. 5 and Supplementary Material: Fig. S1) indicate the change in individual components over different sub-periods. The sub-period variation of individual components sums up to give a total water budget changing through time.

The annual precipitation rate in the area is characterised by periods of dryness and wetness (Supplementary Materials: Fig. S1). The driest period recorded in the coastal area is around the mid-1980s, whereas the wettest period is observed around 2000. In the 1970s-1980 s, the annual precipitation in most parts of Italy was negative in trend. The negative trend in rainfall led to long periods of dryness, resulting in severe freshwater shortage (Piervitali et al. 1998). In a similar period (1971-1986), the annual rainfall in the Ravenna coastal basins dropped to $\sim 492 \mathrm{~mm}$ (a minimum value). Afterward, the amount of rainfall rose to $\sim 760 \mathrm{~mm}$ in 1998 , which is the highest peak of rainfall recorded in the area. Due to natural rainfall variability, its amount dropped again to $593 \mathrm{~mm}$ in 2006 .

The trend of AET (Supplementary Materials: Fig. S1) is dependent on the level of soil moisture content and the amount of rainfall. Therefore, the AET sinusoidal trend is similar to the $\mathrm{P}$ trend. The $\mathrm{P}$ and AET trends are marginally increasing with time in the area, while the PET trend (Supplementary Materials: Fig. S1) is significantly increasing due to a rise in average air temperature. Consequently, the high PET and evaporation in the coastal area will lead to increased water loss from open water surfaces, declining soil water content, and low drainage during the warming months.

Apropos to drainage evolution, between 1971 and 1983, the rate of drainage in all coastal basins is characterised by two apparent peaks seen in 1973 and 1980 (Fig. 5a-c). The pumping rate is high in this period, especially in the San Vitale and Rasponi basins. The reason for the high drainage rate is related to the high subsidence rate and incomplete wetlands drainage. In fact, Simeoni and Bondesan (1997) reported that large freshwater marshes and brackish wetlands present at the beginning of the twentieth century were close to being reclaimed in the 1970s. Another major landmark event between 1971 and 1983 was severe land subsidence (> $65 \mathrm{~mm} /$ year) that promoted inundation in the coastal basins (Carbognin et al. 2011; Carminati and Martinelli 2002; Gambolati et al. 1991; Teatini et al. 2005). At the same time, Adriatic climate-induced sea storms permanently flooded most parts of the Ravenna area in the late 1970s (Teatini et al. 2005). As a result, water management authorities decided to increase the drainage capacity by increasing the number of pumps to reduce flooding and water stagnation where the topography is low and experienced a high subsidence rate.

After 1983, the pumping rate dropped significantly (a minimum in 1987) in the Rasponi and San Vitale basins and remained low until around 1993. The reason for the sudden decline in drainage in all coastal basins is an extended period of drought between 1985 and 1995 (as shown in Fig. 9). By 1995 , the pumping rate in the coastal basins has started to increase again due to a rise in precipitation until 2000. After that, the pumping rate increases steadily with a $22-\mathrm{mm}$ rise in rainfall in a similar period.

\section{Monthly trends}

The rainfall amount received by the coastal basins often increases in the autumn (Sep-Nov) and the spring (Mar-May). The amount of water supplied to the root zone by rainfall $(P \geq$ PET) is the largest during autumn. On the other hand, the amount of rainfall decreases during the summer, particularly in July. The amount of soil moisture stored within the root zone is minimal during the summer due to limited precipitation and high evapotranspiration rates in the area (Supplementary Materials: Fig. S2). The substantial increase in summer temperature further worsens the condition of dryness in the coastal watersheds.

Apropos to drainage, a considerable portion of rain falls during the autumn when drainage is still low. Autumn rainfall has to compensate for water loss during the summer periods (Fig. 6a, 7a, 8a). In the late fall and early winter months, the aquifer eventually gets saturated allowing extra water to reach the drains and the intake canals to the pumps. The rate of daily pumping reaches its peak in winter despite 

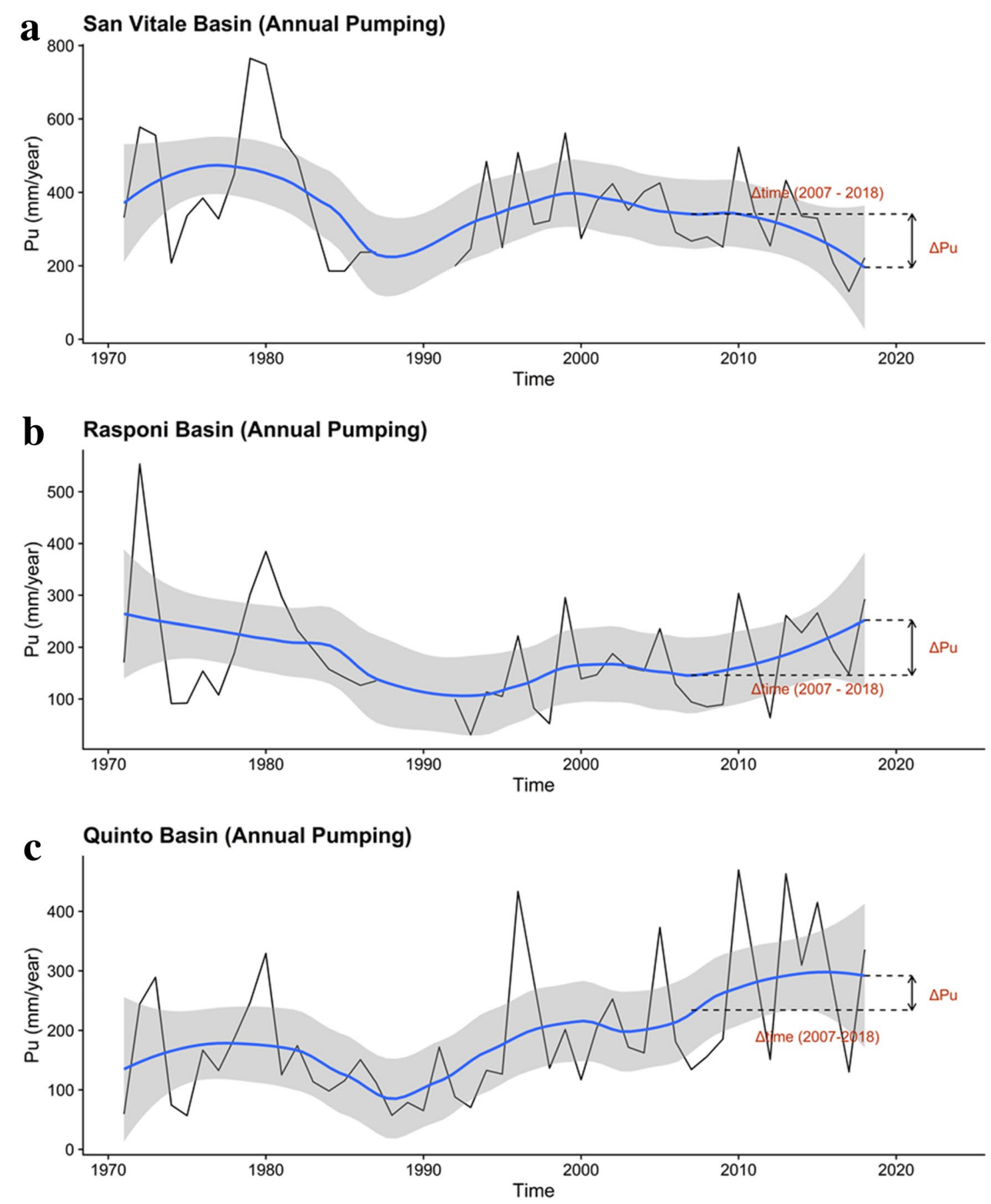

Fig. 5 Annual time series data and modelling of pumping in the following: a San Vitale, b Rasponi, and c Quinto basins from 1971 to 2018 (in mm/year). The blue line is the locally fitted non-parametric

the declining winter rainfall. In summary, the rate of pumping in the three coastal basins depends on the antecedent precipitation and soil-water interaction. Giambastiani et al. (2020) already excluded the influence of the urbanization on drainage series in the Quinto basin and showed no increase or decrease in the correlation between rainfall and curve used to produce a smoothed model surface with the LOESS method; the $95 \%$ confidence interval is shown in grey shading

the equivalent amount of drained water over periods of minimum (1971-1981) and maximum urbanization (2006-2016).

Currently, the coastal basins have a water deficit during the summer and water surplus during the winter when drainage is maximum. Water withdrawal (drainage) and rainfall recharge fluctuations cause stress changes within 

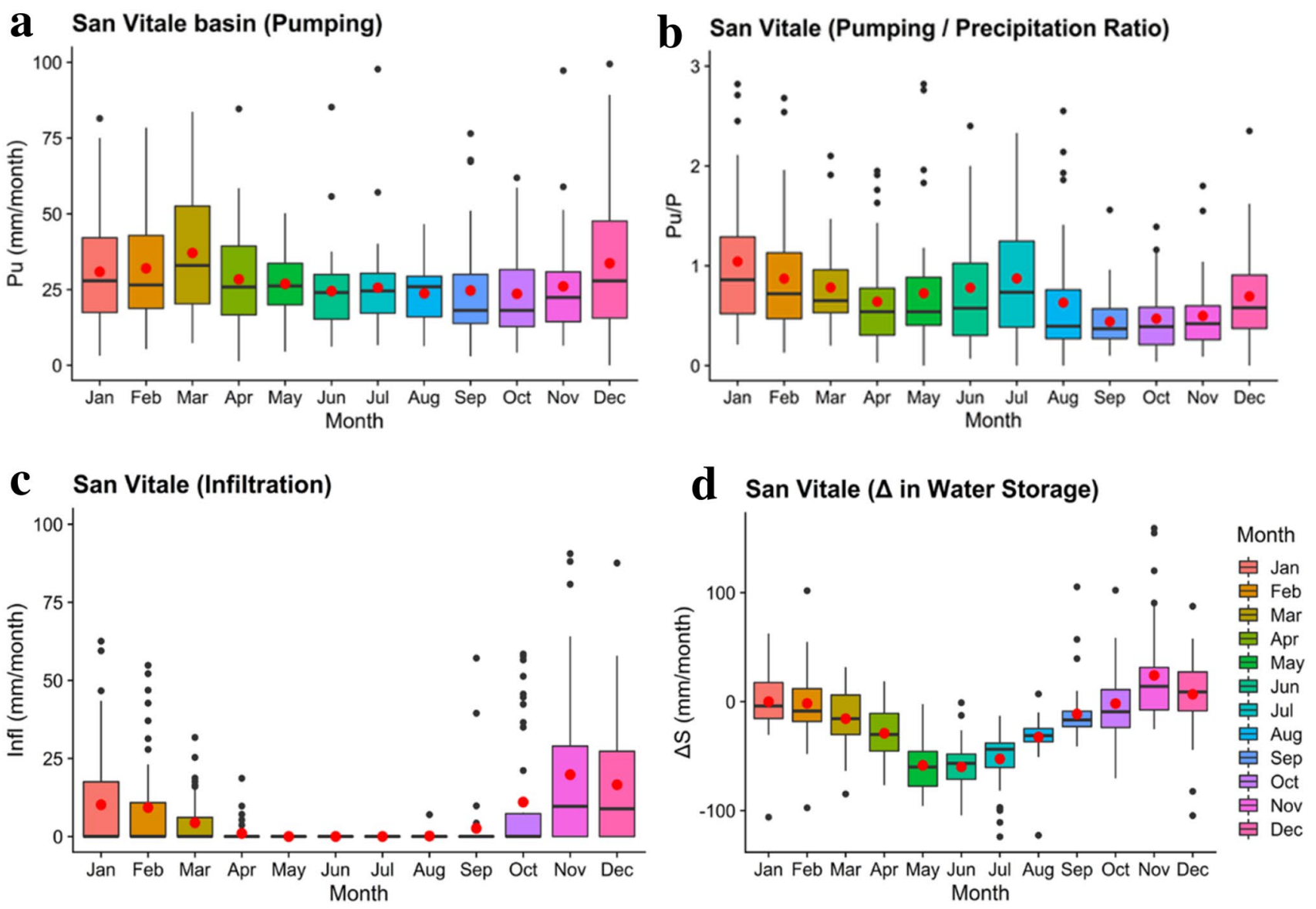

Fig. 6 Monthly boxplot showing: a pumping, b pumping/precipitation ratio, $\mathbf{c}$ infiltration, and $\mathbf{d}$ change in water storage in the San Vitale basin from 1971 to 2018 . The red dot is the mean of the monthly observations

the unconfined aquifer units, similar to natural subsidence mechanisms (Chaussard et al. 2013). The lowering of water level and the soil moisture conditions determined by the intensity of drainage, have an effect on the degree of subsidence, especially where organic material layers (i.e. peat layers) and drained cultivated peatlands are present due to organic matter oxidation (Gambolati et al. 2006; Hoekstra et al. 2020; Wösten et al. 1997; Zanello et al. 2011). Moreover, Antonellini et al. (2019) showed that the elastic and delayed-elastic components of the natural subsidence in the shallow aquifer of this coastal area are closely related to water table fluctuations. These fluctuations change the effective stress at the daily (in the sandy unconfined portion of the aquifer) and seasonal time scales (in the organic-rich fine sediment of the semiconfined prodelta portion), respectively.

Further observation reveals that the infiltration rate (Infl) and change in water storage $(\Delta S)$ become noticeable at the end of the year, resulting in increased baseflow within the drainage canals. Land reclamation authorities often raise the pumping rate in winter to prevent unexpected flooding and waterlogging of the crops where the water table is shallow and close to the topography. However, the $\mathrm{Pu} / \mathrm{P}$ ratio diagram (Fig. 6b, 7b, 8b) shows that the rate of pumping increases in the San Vitale and Quinto basins during the summer, particularly in July. This could be due to specific management practise applied on the two basins, where extensive agriculture practice and important irrigation occur. Here, many canals have a double use, as drainage and irrigation canals, especially during the irrigation season (spring and summer months). The increase in pumping in July could be explained by the return flow, that is the portion of the irrigation water that travels directly from the irrigated fields as surface runoff, as well as the water which has infiltrated into the soil, and part of its flows downstream.

The high summer $\mathrm{Pu} / \mathrm{P}$ ratio value in the Rasponi basin is less apparent than other coastal basins (Fig. 7b).

\section{Climate extreme analysis}

Climate extreme indices calculation is fundamental to detect early climate anomalies and allow for adaptation strategies and prevent societal damages (Zhang et al. 2011). Climate extreme indices that are statistically significant lead to severe impact. Likewise, an insignificant 

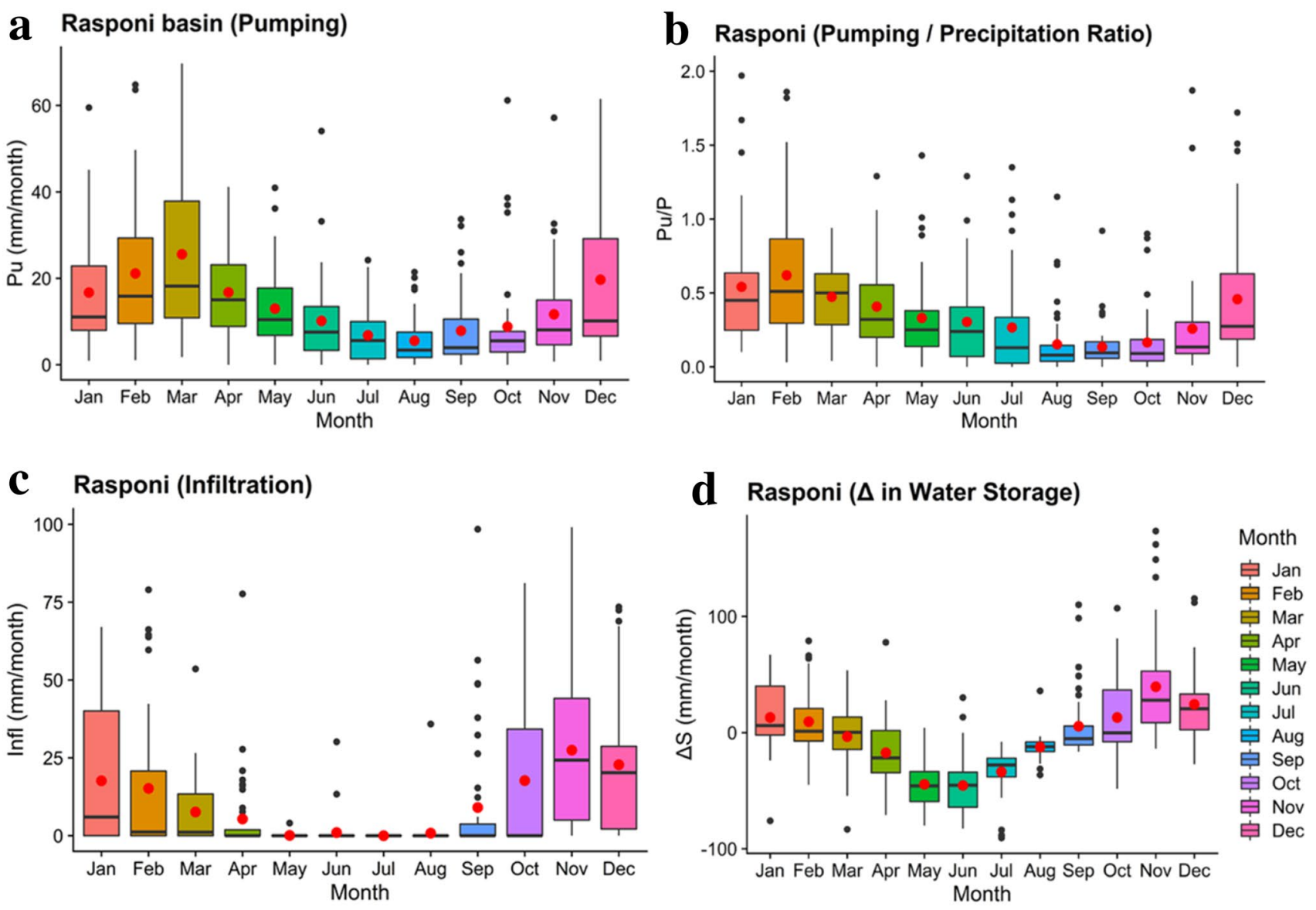

Fig. 7 Monthly boxplot showing: a pumping, b pumping/precipitation ratio, $\mathbf{c}$ infiltration, and $\mathbf{d}$ change in water storage in the Rasponi basin from 1971 to 2018 . The red dot is the mean of the monthly observations

trend does not mean that they are less likely to occur, because an extreme event may result from the accumulation of moderate rainfall events or interaction with other extreme conditions such as storm surge and exceptional tides (Seneviratne et al. 2012). However, most of the warming extremes indices examined are significantly increasing in trend (Table 2). These include SU - 25, GSL, TXx, TX90p, TX10p, TXn, TN10p, and TN90p, CSDI. Significant temperature trends imply that evaporation and evapotranspiration processes will increase in the area, thus partly affecting the water table elevation and the amount of water reaching the vadose aquifer. On the other hand, all extreme rainfall indices trends are weak and not as significant as the warming extremes are (Table 2). This is in line with previous works carried out on a sub-portion of the study area (Quinto basin, Giambastiani et al. 2020) and on the entire coastal aquifer of the Emilia-Romagna (Giambastiani et al. 2021). These studies show no clear rainfall trend and no change in intensity and extreme rainfall events in the last 50 years (1971-2017) in the Ravenna territory.
Apropos to drainage, all trends of extreme rainfall indices slightly increase with a marginal rise in drainage rate except in the San Vitale basin, where they show a negative trend between 2000 and 2018. Based on rainfall trends and documented flood memories in the area (caused by land subsidence, exceptional tides, and storm surges), the coastal drainage infrastructures in the area have increased in numbers and capacity to efficiently and effectively accommodate the processes conveying water into the basin.

The SPI and SPEI drought indices indicate the relationships between drainage and rainfall deficit. The prolonged drought or rainfall deficit witnessed between 1985 and 1995 is seen to be the main factor influencing the drainage rate in all three coastal basins (Fig. 9). The most prolonged dry spell (CDD) and the longest wet spell (CWD) trends are weak and not significant. For this reason, we do not have enough evidence as to whether the CWD and CDD trends will increase or not in the near future. The CDD and CWD are related to the rainfall occurrences, and they can serve as drought indicators, which have great importance to agrometeorologist and water managers (Casanueva et al. 2014). 

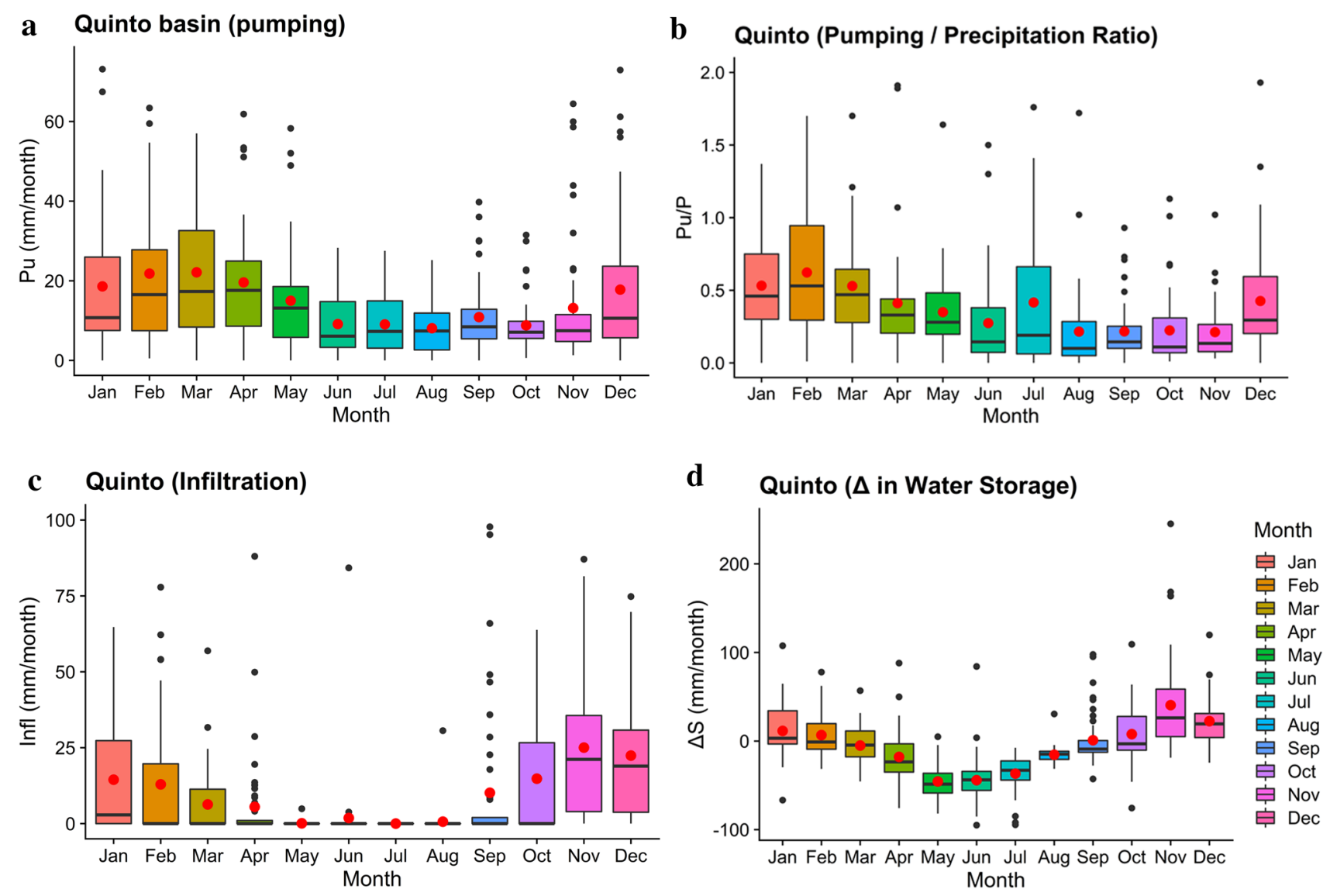

Fig. 8 Monthly boxplot showing: a pumping, b pumping/precipitation ratio, $\mathbf{c}$ infiltration, and $\mathbf{d}$ change in water storage in the Quinto basin from 1971 to 2018 . The red dot is the mean of the monthly observations

\section{Subsidence rate}

The rate of subsidence for the sub-period from 1972 to 1980 is the highest ( $>65 \mathrm{~mm} /$ year) recorded in the past half-century (Supplementary Materials: Fig. S5). This coincides with the development of on-shore and off-shore deep gas exploitation coupled with groundwater withdrawals, which started in the early 1950s and went on until the late 1970s (Carminati et al. 2003).

The subsidence mapping of the low-lying coastal areas shows that the land portion farther from the coastline is more stable with respect to the areas close to the coastline that are sinking faster ( $20 \mathrm{~mm} /$ year $)$, particularly in the Quinto and Rasponi basins. The current rate of land subsidence in the San Vitale basin is smaller than in the other two basins (about $2.5 \mathrm{~mm} /$ year). The subsiding part of the coastal basins poses significant threats to coastal towns, hydraulic infrastructures, and an expansion of the drainage network (new pumping stations, more and more powerful pumps) to cope with a more considerable amount of water to be drained. The increase in hydraulic head difference, driven by land subsidence rates, causes vertical seepage from the bottom of the coastal aquifer and an amount of extra water entering the basin (Giambastiani et al. 2020). In this context, the higher sinking rates observed at the coastal edge of the Quinto and Rasponi basins have promoted more seawater influx into their coastal aquifers compared to the San Vitale basin (Supplementary Material: Fig. S5). These two basins correspond to the most saline portion of the Ravenna territory, with the lowest water table depth, as reported in the reported maps developed by Giambastiani et al. (2021) and related to the entire coastal aquifer of the Emilia-Romagna. The pumping rate is increasing in the Rasponi and the Quinto basins due to the constantly increasing subsidence rates. The San Vitale basin has been relatively stable in the past 15 years, as shown by the decline of drainage rate in this period. Cerenzia et al. (2016) reported that Marina di Ravenna, a town in the San Vitale basin, is recently more stable and emphasized that the forthcoming sub-periods subsidence 
Table 2 Climate extreme indices for the low-lying coastal basins of Ravenna (1971 to 2018)

\begin{tabular}{|c|c|c|}
\hline Index name & Trend/slope & $P$ value \\
\hline \multicolumn{3}{|l|}{ Temperature-based } \\
\hline \multicolumn{3}{|l|}{ Absolute } \\
\hline TXx & +0.042 & $0.044 *$ \\
\hline TXn & +0.071 & $0.008 * *$ \\
\hline TNx & +0.041 & 0.163 \\
\hline $\mathrm{TNn}$ & +0.127 & 0.076 \\
\hline \multicolumn{3}{|l|}{ Percentile } \\
\hline TX10p & -0.339 & $0 * *$ \\
\hline TX90p & +0.21 & $0.001 * *$ \\
\hline TN10p & -0.385 & $0 * *$ \\
\hline TN90p & +0.54 & $0 * *$ \\
\hline \multicolumn{3}{|l|}{ Duration } \\
\hline GSL & +1.341 & $0 * *$ \\
\hline WSDI & +0.059 & 0.474 \\
\hline CSDI & -0.329 & $0.007 * *$ \\
\hline \multicolumn{3}{|l|}{ Threshold } \\
\hline SU25 & +0.64 & $0.009 * *$ \\
\hline FD5 & -0.217 & 0.093 \\
\hline \multicolumn{3}{|l|}{ Precipitation-based } \\
\hline \multicolumn{3}{|l|}{ Absolute } \\
\hline RX1day & +0.208 & 0.373 \\
\hline RX5day & -0.018 & 0.944 \\
\hline \multicolumn{3}{|l|}{ Percentile } \\
\hline R95p & +0.637 & 0.542 \\
\hline R99p & +0.197 & 0.779 \\
\hline CDD & -0.055 & 0.66 \\
\hline CWD & +0.021 & 0.09 \\
\hline \multicolumn{3}{|l|}{ Threshold } \\
\hline $\mathrm{R} 10 \mathrm{~mm}$ & +0.022 & 0.717 \\
\hline $\mathrm{R} 20 \mathrm{~mm}$ & +0.031 & 0.376 \\
\hline \multicolumn{3}{|l|}{ Others } \\
\hline PRCPTOT & +1.581 & 0.34 \\
\hline SDII & +0.011 & 0.476 \\
\hline \multicolumn{3}{|l|}{ Drought indices } \\
\hline SPEI (24 months) & See, Fig. 9 & \\
\hline SPI (24 months) & See, Fig. 9 & \\
\hline
\end{tabular}

Refer to Table 1 for index names, units, and descriptions

*Statistically significant trend at $p=0.05$

**Highly statistically significant trend at $p=0.05$. The significance of the regression at the $95 \%$ level is based on a $t$ test for the estimate of the slope ( $p$ value, 0.05) (Powell and Keim 2014). The negative value $(-v e)$ indicates a declining trend, whereas the positive value $(+\mathrm{ve})$ indicates an increasing trend (Supplementary Materials: Figs. S3-S4; for graphs of extremes)

mapping by Arpae will be useful to either deny or accept the trend.

\section{Water budget analysis}

The sub-period (1971-1986, 1987-1996, 1997-2006, and 2007-2018) water budget trends show the changes in seawater seepage $(\Delta \mathrm{Qs})$, rainfall $(\Delta P)$, evapotranspiration $(\Delta \mathrm{ET})$, and pumping $(\triangle \mathrm{Pu})$ in the coastal basins (Supplementary Materials: Fig. $6 \mathrm{a}-\mathrm{c})$. The input components of each subperiod recharge include vertical seepage of seawater (Qs) and rainfall $(P)$, while the output components include evapotranspiration (ET) and pumping (Pu) (Fig. 4). The Qs increases within the coastal aquifer when AET and Pu components are greater than $P$. On the other hand, the $\mathrm{Qs}$ decreases because the AET and Pu components are lower than $P$.

In the first sub-periods (1971-1986), pumping decreases in all the coastal basins (San Vitale, $\Delta \mathrm{Pu}=-8.3 \mathrm{~mm} / \mathrm{year}$; Rasponi, $\Delta \mathrm{Pu}=-7.8 \mathrm{~mm} /$ year; Quinto, $\Delta \mathrm{Pu}=-2.1 \mathrm{~mm} /$ year) with decrease in rainfall $(-14.6 \mathrm{~mm} /$ year). The output components are greater than rainfall recharge, so vertical seepage through the shallow unconfined aquifer increases (San Vitale, $\Delta \mathrm{Qs}=1.5 \mathrm{~mm} /$ year; Rasponi, $\Delta \mathrm{Qs}=2.1 \mathrm{~mm} /$ year; Quinto, $\Delta \mathrm{Qs}=7.7 \mathrm{~mm} /$ year). In this period, vertical seepage increment plays a more important role by contributing more to water table elevation with implications for freshwater availability.

During the next sub-period (1987-1996), pumping in the Quinto $(\Delta \mathrm{Pu}=11.61 \mathrm{~mm} / \mathrm{year})$ and San Vitale basins $(\Delta \mathrm{Pu}=15.4 \mathrm{~mm} / \mathrm{year})$ increases with an increase in rainfall recharge $(31.2 \mathrm{~mm} /$ year), while it slightly decreases in the Rasponi basin $(\Delta \mathrm{Pu}=-0.1 \mathrm{~mm} /$ year). Despite this, the output components are lower than rainfall in all coastal basins, and so the vertical seepage decreases everywhere (San Vitale, $\Delta \mathrm{Qs}=-1.4 \mathrm{~mm} /$ year; Quinto, $\Delta \mathrm{Qs}=-5.2 \mathrm{~mm} /$ year; Rasponi, $\Delta \mathrm{Qs}=-17.6 \mathrm{~mm} /$ year). In this case, rainfall for this sub-period is enough to counterbalance saline intrusion because the sum of changes in processes that promote salinity (seepage, ET, and pumping) are lower than rainfall in this period.

From 1997 to 2006, pumping in the Rasponi and Quinto basin increases (Quinto, $\Delta \mathrm{Pu}=2.3 \mathrm{~mm} /$ year; Rasponi, $\Delta \mathrm{Pu}=0.8 \mathrm{~mm} /$ year$)$ as rainfall decreases $(-20.1 \mathrm{~mm} /$ year $)$. The current sub-period decline in rainfall is not as drastic as the 1971-1986 drop. In contrast, the pumping in the San Vitale basin decreases $(\Delta \mathrm{Pu}=-6.4 \mathrm{~mm} /$ year $)$. The output components are greater than the rainfall input and consequently vertical seepage flow into the unconfined aquifer increases in all basins (San Vitale, $\Delta \mathrm{Qs}=4.5 \mathrm{~mm} / \mathrm{year}$; Quinto, $\Delta \mathrm{Qs}=13.2 \mathrm{~mm} /$ year; Rasponi, $\Delta \mathrm{Qs}=11.7 \mathrm{~mm} /$ year). Since the amount of water leaving the shallow aquifer is higher than the rainfall input, the upward-directed seawater seepage has contributed more to the water table increase in this period. 

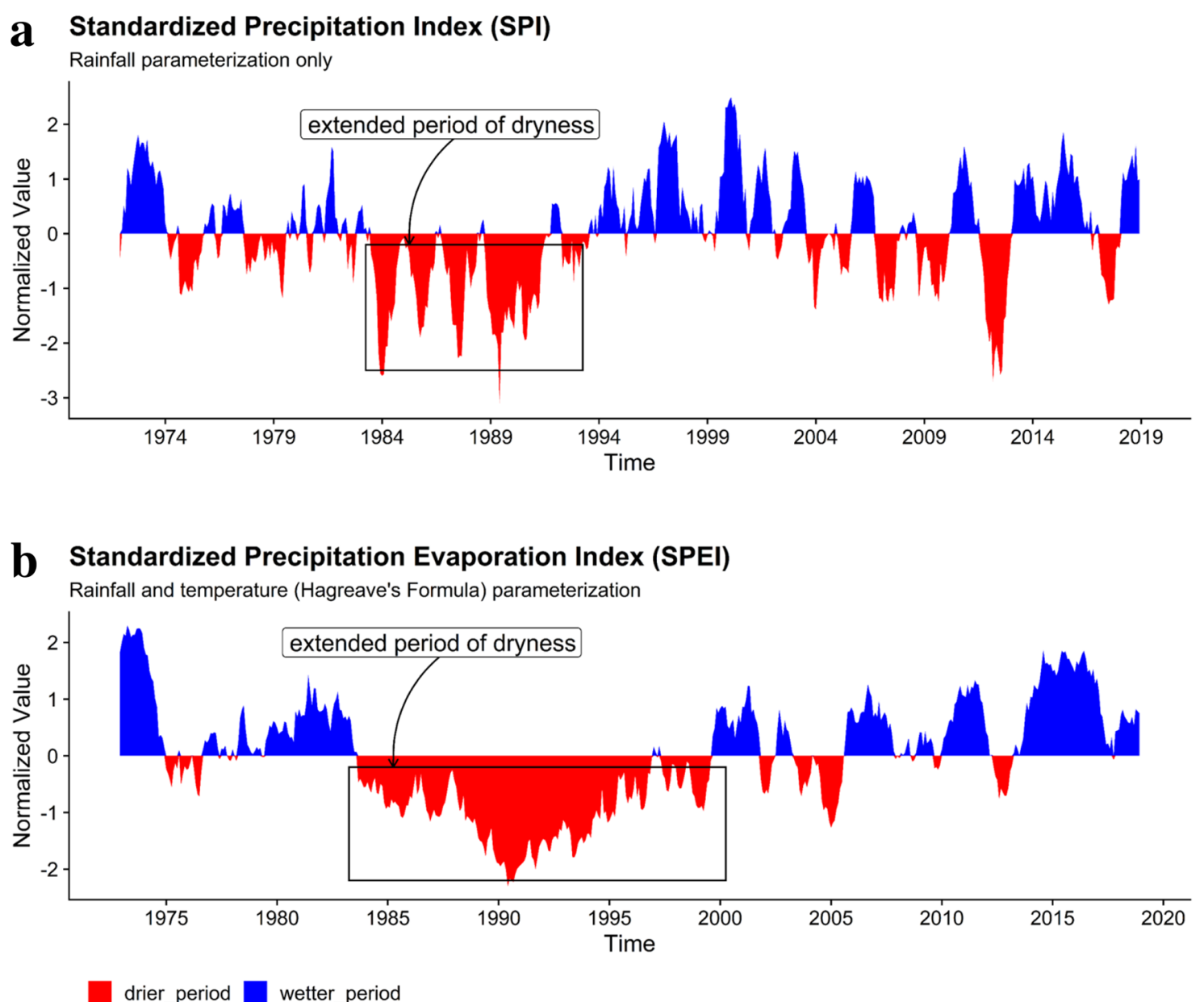

Fig. 9 Monthly series for drought indices in the low-lying areas: a showing the SPI, and b the SPEI index from 1971 to 2018 . Positive SPI values indicate higher than median precipitation, whereas negative values indicate less than median precipitation.

During the last period (2007 to 2018), pumping increases for both Quinto and Rasponi basin (Quinto, $\Delta \mathrm{Pu}=5.2 \mathrm{~mm}$ / year, Rasponi, $\Delta \mathrm{Pu}=9.6 \mathrm{~mm} /$ year). On the other hand, pumping continues to decline in the San Vitale basin from the last sub-period (current sub-period $\Delta \mathrm{Pu}=-17.2 \mathrm{~mm} /$ year) despite the increase in rainfall. The output components are higher than rainfall in Rasponi, while they are lower for San Vitale and Quinto basins. Consequently, the vertical seepage in the Rasponi basin increases ( $\Delta \mathrm{Qs}=1.2 \mathrm{~mm} /$ year), while it decreases for the other two basins (Quinto, $\Delta \mathrm{Qs}=-3.2 \mathrm{~mm} /$ year; San Vitale, $\Delta \mathrm{Qs}=-25.7 \mathrm{~mm} / \mathrm{year})$. The current declining pumping rate in the San Vitale basin is remarkable, as also observed in the last sub-period 1997-2006. The significant reduction in upward seepage through the shallow unconfined aquifer of the San Vitale basin also explains the current reduction in pumping.

Over the last 48 years, the overall vertical seepage strongly decreases with a significant decrease in pumping in the San Vitale basin (Supplementary Materials: Fig. S6a); the same occurs in the Rasponi basin even if at a lower rate (Supplementary Materials: Fig. S6b). The positive vertical seepage in the Quinto basin, on the other hand, contributes more to water table rise and, as a result, an increase in drainage rate (Supplementary Materials: Fig. S6c). This agrees with the increased hydraulic vertical gradient calculated for the Quinto basin (period 1971-2017) by Giambastiani et al. (2020) and resulting in about 139-92 mm of a total equivalent amount of water due to vertical seepage. The increase or decrease in drainage and seepage can cause a similar change in freshwater availability and water table elevation within the coastal aquifer. However, rainfall and evapotranspiration also affect the water elevation table and change in freshwater availability; for instance, more rainfall recharge counteracts other processes that promote aquifer salinity such as seepage, drainage, and ET. 


\section{Summary and conclusions}

The coastal areas worldwide are at risk for climate change effects and land subsidence problems. There is a need to adequately inform the coastal communities, coastal managers, and scientists interested in how climate extremes and land flooding could shape the future of freshwater availability and mitigation measures put in place. In this context, the conclusions addressed in this study could serve as a motivation and reference to understand other coastal areas undergoing similar conditions worldwide.

The results of this study show that the drainage behaviour in the coastal basins is influenced by land subsidence, past management practices, and climate variability. Climate change indicators (such as wet periods, drought periods) and land modification indicators (such as reclamation, groundwater and gas extraction) have profoundly controlled surface water drainage evolution. The most important indices to monitor drainage evolution are the drought indices: SPI and SPEI; they allow detecting the precipitation severity in terms of wetness and dryness and permit easy comparison of them with drainage evolution along time scale.

Land subsidence causes an increase in upward-directed vertical seepage of saline water into the coastal aquifer and the drainage network. This leads to an increase in drainage through time that promotes salinization and a decrease in freshwater availability. The vertical seawater seepage could cause significant long-term concern for ground and surface water users in the low-lying coastal basins.

The period characterized by the highest subsidence rate (1950-1970 s) had a more significant influence on drainage than in any other period and promoted more seawater influx into the aquifer. The upward-directed vertical seepage of saline water through the shallow unconfined aquifer in the most subsiding basin (Quinto basin) has enormously contributed to the increase in the drainage rate due to the extra water influx reaching the drainage canals. On the contrary, a decrease in land subsidence rates in the San Vitale basin has decreased seepage from the aquifer bottom, thus contributing significantly to the decline in pumping rate and water table rise.

On the other hand, drainage has proven to be an essential mitigation infrastructure in the low-lying coastal basins to mitigate potential inundation, but with a long-term impact on water resources management and planning. An effort should be made to control the depth of drainage by keeping the water table depth as small as possible, while maintaining agricultural crop requirements. Accurate planning and timely control of the drainage system and the pumping station activity can be used to obtain this control.

The coastal basins are currently characterized by water deficit during the summer and water surplus during the winter, when aquifer gets saturated by autumn rain and drainage is maximum. At the seasonal timescale, the rate of pumping depends on antecedent rainfall and soil-water storage. The abundant autumn rainfall does not correlate with an increase in drainage until the end of November or December, because the soil water storage needs to be restored before a rise in water table triggers drainage. The freshwater availability in the area is becoming scarce due to limited rainfall, persistent water drainage, and long periods of drought. Drainage activities in the coastal basins have prevented rainfall recharge and the vadose soil from receiving enough freshwater to counteract the saltwater intrusion.

The detailed analysis carried out in sub-periods for different mechanically drained coastal basins highlights the temporal (i.e., periods in which seepage does not exist) and spatial variability of the processes, and emerges that an upscaling cannot be done without considering the water budgets of the individual basins. The novelty of our study is showing that there is no single process controlling a change in drainage but there are many and complexly interrelated. Land subsidence, climate variability, climate extremes, as well as past management practices all play an important role. We show that there is a wide range of factors that affect drainage time series and knowledge gained from a single basin cannot be extrapolated to the whole coastal area. Therefore, water management practices in this coastal zone should be tailored to the specific characteristics (hydrologic balance response) of the basin and focus on those processes that mostly affect drainage.

Supplementary Information The online version contains supplementary material available at https://doi.org/10.1007/s12665-021-09774-5.

Acknowledgements We would like to thank the Arpae (Regional Agency for Prevention, Environmental, and Energy of EmiliaRomagna, Italy) and Land Reclamation Consortium (Consorzio di Bonifica della Romagna, Ravenna, Italy) for making available the subsidence survey and the drainage data, respectively. My [Lukman A. Soboyejo] sincere gratitude goes to all Water and Coastal Management (WaCoMa) coordinators (https://wacoma.unibo.it/home.php) as well as the European Union for the Erasmus Mundus Joint Master Degree (EMJMD) Programme and Scholarship provided as part of the 20182020 cohort at the University of Bologna-Italy, the University of Cadiz-Spain, and the University of Algarve-Portugal.

Author contributions Conceptualization, Methodology: [LAS, MA, BMSG]; Formal analysis and investigation: [LAS, BMSG, MA]; Writing-original draft preparation: [LAS]; Writing-review and editing: [LAS, MA, BMSG]; Resources: [MM]; Supervision: [MA, BMSG]. All authors have read and agreed to the published version of the manuscript.

Funding Open access funding provided by Alma Mater Studiorum Università di Bologna within the CRUI-CARE Agreement. 


\section{Declarations}

Conflict of interest The authors declare that they have no competing interest.

Open Access This article is licensed under a Creative Commons Attribution 4.0 International License, which permits use, sharing, adaptation, distribution and reproduction in any medium or format, as long as you give appropriate credit to the original author(s) and the source, provide a link to the Creative Commons licence, and indicate if changes were made. The images or other third party material in this article are included in the article's Creative Commons licence, unless indicated otherwise in a credit line to the material. If material is not included in the article's Creative Commons licence and your intended use is not permitted by statutory regulation or exceeds the permitted use, you will need to obtain permission directly from the copyright holder. To view a copy of this licence, visit http://creativecommons.org/licenses/by/4.0/.

\section{References}

Abdoulhalik A, Ahmed AA (2018) Transience of seawater intrusion and retreat in response to incremental water-level variations. Hydrol Process 32:2721-2733. https://doi.org/10.1002/hyp.13214

Amorosi C, Pasini P (1999) Sedimentary response to late quaternary sea-level changes in the Romagna coastal plain (northern Italy). Sedimentology 46:99-121. https://doi.org/10.1046/j.1365-3091. 1999.00205.x

Amorosi A, Dinelli E, Rossi V, Vaiani SC, Sacchetto M (2008) Late quaternary palaeoenvironmental evolution of the Adriatic coastal plain and the onset of Po River Delta. Palaeogeogr Palaeoclimatol Palaeoecol 268:80-90. https://doi.org/10.1016/j.palaeo.2008.07. 009

Antonellini M, Mollema P, Giambastiani B, Bishop K, Caruso L, Minchio A, Pellegrini L, Sabia M, Ulazzi E, Gabbianelli G (2008) Saltwater intrusion in the coastal aquifer of the southern Po Plain Italy. Hydrogeol J Heidelb 16:1541-1556. https://doi.org/10.1007/ s10040-008-0319-9

Antonellini M, Allen DM, Mollema PN, Capo D, Greggio N (2015) Groundwater freshening following coastal progradation and land reclamation of the Po Plain. Italy Hydrogeol J 23:1009-1026. https://doi.org/10.1007/s10040-015-1263-0

Antonellini M, Giambastiani BMS, Greggio N, Bonzi L, Calabrese L, Luciani P, Perini L, Severi P (2019) Processes governing natural land subsidence in the shallow coastal aquifer of the Ravenna coast, Italy. CATENA 172:76-86. https://doi.org/10.1016/j.catena. 2018.08.019

Artese G, Fiaschi S, Di Martire D, Tessitore S, Fabris M, Achilli V, Ahmed A, Borgstrom S, Calcaterra D, Ramondini M, Artese S, Floris M, Menin A, Monego M, Siniscalchi V (2016) Monitoring of land subsidence in Ravenna municipality using integrated SAR - GPS techniques: description and first results. In: Presented at the international archives of the photogrammetry, remote sensing and spatial information sciences-ISPRS archives, pp. 23-28

Benini L, Antonellini M, Laghi M, Mollema PN (2016) Assessment of water resources availability and groundwater salinization in future climate and land use change scenarios: a case study from a coastal drainage basin in Italy. Water Resour Manag Dordr 30:731-745. https://doi.org/10.1007/s11269-015-1187-4

Bitelli G, Bonsignore F, Pellegrino I, Vittuari L (2015) Evolution of the techniques for subsidence monitoring at regional scale: the case of Emilia-Romagna region (Italy). In: Presented at the proceedings of the international association of hydrological sciences, pp. 315-321

Campo B, Amorosi A, Vaiani SC (2017) Sequence stratigraphy and late quaternary paleoenvironmental evolution of the Northern Adriatic coastal plain (Italy). Palaeogeogr Palaeoclimatol Palaeoecol 466:265-278. https://doi.org/10.1016/j.palaeo.2016.11.016

Carbognin L, Teatini P, Tosi L, Strozzi T, Tomasin A (2011) Present relative sea level rise in the northern adriatic coastal area. In: Brugnoli E, Cavarretta G, Mazzola S, Trincardi F, Ravaioli M, Santoleri R (eds) Coastal and marine spatial planning. CNR Dipartimento Scienze del Sistema Terra e Tecnologie, Roma, pp $1147-1162$

Carminati E, Martinelli G (2002) Subsidence rates in the Po Plain, northern Italy: the relative impact of natural and anthropogenic causation. Eng Geol 66:241-255. https://doi.org/10.1016/ S0013-7952(02)00031-5

Carminati E, Doglioni C, Scrocca D (2003) Apennines subductionrelated subsidence of Venice (Italy). Geophys Res Lett. https:// doi.org/10.1029/2003GL017001

Casanueva A, Rodríguez-Puebla C, Frías MD, González-Reviriego N (2014) Variability of extreme precipitation over Europe and its relationships with teleconnection patterns. Hydrol Earth Syst Sci 18:709-725. https://doi.org/10.5194/hess-18-709-2014

Cerenzia I, Putero D, Bonsignore F, Galassi G, Olivieri M, Spada G (2016) Historical and recent sea-level rise and land subsidence in Marina di Ravenna, northern Italy. Ann Geophys. https://doi. org/10.4401/ag-7022

Chaussard E, Amelung F, Abidin H, Hong S-H (2013) Sinking cities in Indonesia: ALOS PALSAR detects rapid subsidence due to groundwater and gas extraction. Remote Sens Environ 128:150 161. https://doi.org/10.1016/j.rse.2012.10.015

Cleveland WS (1979) Robust locally weighted regression and smoothing scatterplots. J Am Stat Assoc 74:829-836. https:// doi.org/10.1080/01621459.1979.10481038

Cleveland WS, Devlin SJ (1988) Locally weighted regression: an approach to regression analysis by local fitting. J Am Stat Assoc 83:596-610. https://doi.org/10.1080/01621459.1988.10478639

Cleveland WS, Grosse E, Shyu WM (2007) Local regression models. In: Statistical models in S. Routledge, pp. 309-376. https://doi. org/10.1201/9780203738535-8

Essink GHPO, van Baaren ES, de Louw PGB (2010) Effects of climate change on coastal groundwater systems: a modeling study in the Netherlands. Water Resour Res. https://doi.org/10.1029/ 2009WR008719

Galloway DL, Jones DR, Ingebritsen SE (1999) Land subsidence in the United States (USGS Numbered Series No. 1182), Land subsidence in the United States, Circular. U.S. Geological Survey. https://doi.org/10.3133/cir1182

Gambolati G, Ricceri G, Bertoni W, Brighenti G, Vuillermin E (1991) Mathematical simulation of the subsidence of Ravenna. Water Resour Res 27:2899-2918. https://doi.org/10.1029/ 91WR01567

Gambolati G, Putti M, Teatini P, Gasparetto Stori G (2006) Subsidence due to peat oxidation and impact on drainage infrastructures in a farmland catchment south of the Venice Lagoon. Environ Geol 49:814-820. https://doi.org/10.1007/ s00254-006-0176-6

Giambastiani BMS, Antonellini M, Oude Essink GHP, Stuurman RJ (2007) Saltwater intrusion in the unconfined coastal aquifer of Ravenna (Italy): a numerical model. J Hydrol 340:91-104. https:// doi.org/10.1016/j.jhydrol.2007.04.001

Giambastiani BMS, Mollema PN, Antonellini M (2008) Groundwater management in the Northern Adriatic Coast (Ravenna, Italy): new strategy to protect the coastal aquifer from saltwater intrusion. Nova Science Publishers, Inc., pp. 203-229 
Giambastiani BMS, Macciocca VR, Molducci M, Antonellini M (2020) Factors affecting water drainage long-time series in the salinized low-lying coastal area of ravenna (Italy). Water 12:256. https:// doi.org/10.3390/w12010256

Giambastiani BMS, Kidanemariam A, Dagnew A, Antonellini M (2021) Evolution of salinity and water table level of the phreatic coastal aquifer of the emilia romagna region (Italy). Water 13:372. https://doi.org/10.3390/w13030372

Greggio N, Mollema P, Antonellini M, Gabbianelli G (2012) Irrigation management in coastal zones to prevent soil and groundwater salinization. Resour Manag Sustain Agric. https://doi.org/10. $5772 / 50534$

Greggio N, Giambastiani BMS, Antonellini M (2018) Infiltration/ irrigation trench for sustainable coastal drainage management: Emilia-Romagna (Italy). Environ Eng Manag J 17:2379-2390

Hayes MJ, Svoboda M, Mark D, Wilhite DA, Vanyarkho OV (1999) Monitoring the 1996 drought using the standardized precipitation index. Bull Am Meteorol Soc 80:429-438

Hoekstra J, van Schie A, van Hardeveld HA (2020) Pressurized drainage can effectively reduce subsidence of peatlands-lessons from polder Spengen, the Netherlands. Proc Int Assoc Hydrol Sci 382:741-746. https://doi.org/10.5194/piahs-382-741-2020

ISPRA (2013) Variazioni e tendenze degli estremi di temperatura e precipitazione in Italia. Stato dell'Ambiente (Authors; Guido Fioravanti, Emanuela Piervitali, Franco Desired One, Walter Perconti, Piero Fraser)

Loader C (2012) Smoothing: local regression techniques. In: Gentle JE, Härdle WK, Mori Y (eds) Handbook of computational statistics: concepts and methods springer handbooks of computational statistics. Springer, Berlin, pp 571-596

McKee TB, Doesken NJ, Kleist J (1993) The relationship of drought frequency and duration to time scales. Eighth Conf Appl Climatol $22: 179-184$

Mimura N (2021) Rising seas and subsiding cities. Nat Clim Chang. https://doi.org/10.1038/s41558-021-01009-6

Mollema P, Antonellini M, Gabbianelli G, Laghi M, Marconi V, Minchio A (2012) Climate and water budget change of a Mediterranean coastal watershed, Ravenna, Italy. Environ Earth Sci 65:257-276. https://doi.org/10.1007/s12665-011-1088-7

Nazarnia H, Nazarnia M, Sarmasti H, Wills WO (2020) A systematic review of civil and environmental infrastructures for coastal adaptation to sea level rise. Civ Eng J 6:1375-1399

Nicholls RJ, Wong PP, Burkett V, Codignotto J, Hay J (2007) Coastal systems and low-lying areas. Climate change 2007: impacts, adaptation, and vulnerability. Contribution of Working Group II to the Fourth Assessment Report of the Intergovernmental Panel on Climate Change. Cambridge University Press, Cambridge, UK, pp. 315-356.

Nicholls RJ, Lincke D, Hinkel J, Brown S, Vafeidis AT, Meyssignac B, Hanson SE, Merkens J-L, Fang J (2021) A global analysis of subsidence, relative sea-level change and coastal flood exposure. Nat Clim Chang. https://doi.org/10.1038/s41558-021-00993-z

Ogie RI, Perez P, Win KT, Michael K (2018) Managing hydrological infrastructure assets for improved flood control in coastal megacities of developing nations. Urban Clim 24:763-777. https://doi. org/10.1016/j.uclim.2017.09.002

Piervitali E, Colacino M, Conte M (1998) Rainfall over the centralwestern mediterranean basin in the period 1951-1995. Part Precip Trends 21:331-344

Powell EJ, Keim BD (2014) Trends in daily temperature and precipitation extremes for the southeastern United States: 1948-2012. J Clim 28:1592-1612. https://doi.org/10.1175/JCLI-D-14-00410.1

Seneviratne SI, Nicholls N, Easterling D, Goodess CM, Kanae S, Kossin J, Luo Y, Marengo J, McInnes K, Rahimi M, Reichstein M, Sorteberg A, Vera C, Zhang X, Rusticucci M, Semenov V,
Alexander LV, Allen S, Benito G, Cavazos T, Clague J, Conway D, Della-Marta PM, Gerber M, Gong S, Goswami BN, Hemer M, Huggel C, van den Hurk B, Kharin VV, Kitoh A, Tank AMGK, Li G, Mason S, McGuire W, van Oldenborgh GJ, Orlowsky B, Smith S, Thiaw W, Velegrakis A, Yiou P, Zhang T, Zhou T, Zwiers FW (2012) Changes in climate extremes and their impacts on the natural physical environment. In: Field CB, Barros V, Stocker TF, Dahe Q (eds) Managing the risks of extreme events and disasters to advance climate change adaptation. Cambridge University Press, Cambridge, pp 109-230. https://doi.org/10.1017/CBO97 81139177245.006

Sestini G (1996) Land subsidence and sea-level rise: the case of the Po Delta Region, Italy. In: Milliman JD, Haq BU (eds) Sea-level rise and coastal subsidence: causes, consequences, and strategies, coastal systems and continental margins. Springer, Dordrecht, pp 235-248. https://doi.org/10.1007/978-94-015-8719-8_13

Simeoni U, Bondesan M (1997) The role and responsibility of man in the evolution of the Italian Adriatic coast. Bull Inst Oceanogr Monaco. In: Transformations and evolution of the Mediterranean coastline, pp 111-132

Steenhuis TS, Van Der Molen WH (1986) The Thornthwaite-Mather procedure as a simple engineering method to predict recharge. J Hydrol 84:221-229. https://doi.org/10.1016/0022-1694(86) 90124-1

Stefani M, Vincenzi S (2005) The interplay of eustasy, climate, and human activity in the late Quaternary depositional evolution and sedimentary architecture of the Po Delta system. Mar Geol Mediterr Prodelta Syst 222-223:19-48. https://doi.org/10.1016/j. margeo.2005.06.029

Stefani M, Zuppiroli M (2010) The interaction of geological and anthropic processes shaping the urban growth of Ferrara and the evolution of the surrounding plain

Syvitski JPM, Kettner AJ, Overeem I, Hutton EWH, Hannon MT, Brakenridge GR, Day J, Vörösmarty C, Saito Y, Giosan L, Nicholls RJ (2009) Sinking deltas due to human activities. Nat Geosci 2:681-686. https://doi.org/10.1038/ngeo629

Teatini P, Ferronato M, Gambolati G, Bertoni W, Gonella M (2005) A century of land subsidence in Ravenna, Italy. Environ Geol Berl 47:831-846. https://doi.org/10.1007/s00254-004-1215-9

Teatini P, Ferronato M, Gambolati G, Gonella M (2006) Groundwater pumping and land subsidence in the Emilia-Romagna coastland, Italy: modeling the past occurrence and the future trend. Water Resour Res. https://doi.org/10.1029/2005WR004242

Thornthwaite CW (1948) An approach toward a rational classification of climate. Geogr Rev 38:55-94. https://doi.org/10.2307/210739

Thornthwaite C, Mather JR (1955) The water balance. Publ Climatol 8:1-104

Thornthwaite CW, Mather JR (1957) Instructions and tables for computing potential evapotranspiration and the water balance [WWW Document]. World Veg Cent https://worldveg.tind.io/record/3826. Accessed 5 Jan 2021

Tomozeiu R, Cacciamani C, Pavan V, Morgillo A, Busuioc A (2006) Climate change scenarios for surface temperature in Emilia-Romagna (Italy) obtained using statistical downscaling models. Theor Appl Climatol 90:25. https://doi.org/10.1007/ s00704-006-0275-z

Van Straaten LMJU (1970) Holocene and late-Pleistocene sedimentation in the Adriatic Sea. Geol Rundsch 60:106-131. https://doi. org/10.1007/BF01820934

Vandenbohede A, Mollema PN, Greggio N, Antonellini M (2014) Seasonal dynamic of a shallow freshwater lens due to irrigation in the coastal plain of Ravenna. Italy Hydrogeol J 22:893-909. https:// doi.org/10.1007/s10040-014-1099-z

Vicente-Serrano SM, Beguería S, Gimeno L, Eklundh L, Giuliani G, Weston D, El Kenawy A, López-Moreno JI, Nieto R, Ayenew T, 
Konte D, Ardö J, Pegram GGS (2012) Challenges for drought mitigation in Africa: the potential use of geospatial data and drought information systems. Appl Geogr 34:471-486. https://doi.org/10. 1016/j.apgeog.2012.02.001

World Meteorological Organization (2012) Standardized precipitation index user guide

Wösten JHM, Ismail AB, van Wijk ALM (1997) Peat subsidence and its practical implications: a case study in Malaysia. Geoderma 78:25-36. https://doi.org/10.1016/S0016-7061(97)00013-X

Zanello F, Teatini P, Putti M, Gambolati G (2011) Long term peatland subsidence: experimental study and modeling scenarios in the
Venice coastland. J Geophys Res Earth Surf. https://doi.org/10. 1029/2011JF002010

Zhang X, FengY, Chan R (2018) Introduction to RClimDex v1.9

Zhang X, Alexander L, Hegerl GC, Jones P, Tank AK, Peterson TC, Trewin B, Zwiers FW (2011) Indices for monitoring changes in extremes based on daily temperature and precipitation data. Wires Clim Chang 2:851-870. https://doi.org/10.1002/wcc.147

Publisher's Note Springer Nature remains neutral with regard to jurisdictional claims in published maps and institutional affiliations. 